JULIANA LIMA DE REGUEIRO

\title{
TURISMO E RELAÇÕES INTERNACIONAIS: \\ UM ESTUDO DE CASO COMPARADO ENTRE \\ BRASIL E DUBAI
}

Trabalho de conclusão do curso de Relações Internacionais para a Universidade de Brasília, apresentado como requisito parcial à obtenção do título de Especialista em Relações Internacionais 
JULIANA LIMA DE REGUEIRO

TURISMO E RELAÇÕES INTERNACIONAIS:

UM ESTUDO DE CASO COMPARADO ENTRE BRASIL E DUBAI

Trabalho de conclusão do curso de Relações Internacionais para a Universidade de Brasília, apresentado como requisito parcial à obtenção do título de Especialista em Relações Internacionais

Orientador:

Prof. Dr. Carlos Roberto Pio da Costa Filho

\section{Brasília}


FICHA CATALOGRÁFICA

Regueiro, Juliana Lima de

Turismo e Relações Internacionais: um estudo de caso comparado entre Brasil e Dubai/ Juliana Lima de Regueiro; Orientador : Carlos Roberto Pio da Costa Filho - Brasil, 2009

$72 p$.

Trabalho de Conclusão de Curso. Instituto de Relações Internacionais/ Universidade de Brasília. Curso de Especialização em Relações Internacionais.

1. Turismo. 2. Relações Internacionais. 3. Brasil 4. Dubai Instituto de Relações Internacionais 
Agradeço ao Professor Doutor Carlos Roberto Pio da Costa Filho pela extrema paciência e dedicação com que me orientou para a conclusão deste trabalho. 


\section{RESUMO}

O objetivo deste trabalho é demonstrar a confluência dos campos de estudo das relações internacionais e do turismo e, ao mesmo tempo, traçar um paralelo entre dois casos específicos a serem comparados, Dubai e Brasil. Para tanto, serão abordadas as principais teorias clássicas e temas e agendas mais debatidos atualmente pelas RI, assim como a institucionalização, a economia e elementos gerais do setor turístico. Quanto aos estudos de casos, serão promovidas comparações e análises relativamente à descrição de fatores tais como políticas públicas, influências sócioeconômicas, dados geográficos e históricos, dentre outros aspectos relevantes para ambos os campos de estudo. 


\begin{abstract}
This study intends to demonstrate the confluence of two fields of study, International Relations and Tourism, while drawing a parallel between two specific cases, Dubai and Brazil. Therefore, the classic theories of the International Relations, as well as its most lately discussed agenda themes will be approached. Concerning the cases, analysis and comparisons will be proposed relatively to descriptions, such as public politics, socioeconomic influences, geographic and historical data, among other relevant aspects for both fields.
\end{abstract}




\section{SUMÁRIO}

\begin{tabular}{|c|c|c|}
\hline Introdu & ção............ & 8 \\
\hline Capítı & Io 1 Turismo Internacional como Objeto de Estudo...... & 13 \\
\hline 1.1 & 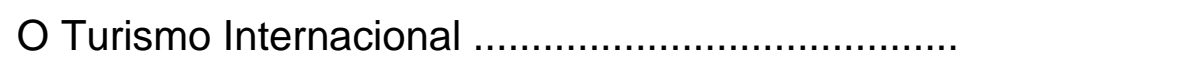 & 14 \\
\hline 1.2 & O Turismo como Atividade Econômica.... & 15 \\
\hline 1.3 & O Contexto Internacional e a Institucionalização do Turismo....... & 18 \\
\hline Capítı & lo 2 Teorias das Relações Internacionais.. & 23 \\
\hline 2.1 & Realismo .... & 25 \\
\hline 2.2 & Liberalismo . & 26 \\
\hline 2.3 & 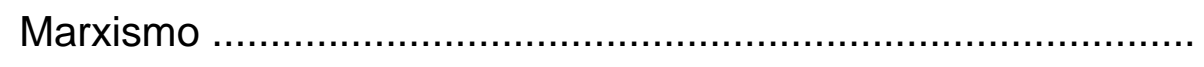 & 29 \\
\hline & lo 3 Confluência dos Campos de Estudo: Relações & \\
\hline Interna & 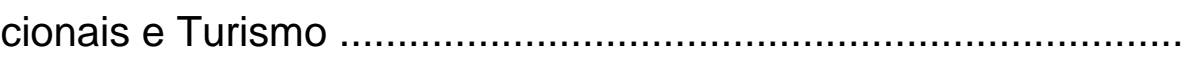 & 31 \\
\hline 3.1 & Meio Ambiente.. & 31 \\
\hline 3.2 & Cultura.. & 36 \\
\hline 3.3 & Segurança.. & 39 \\
\hline 3.4 & Fluxos Migratórios... & 42 \\
\hline 3.5 & Direitos Humanos ........ & 45 \\
\hline 3.6 & Desenvolvimento e Combate à Pobreza.. & 47 \\
\hline Capítu & Io 4 Dubai e Brasil: Descrições, Similaridades e Disparidades.. & 52 \\
\hline 4.1 & Dubai: A Formação de um Emirado Cosmopolita......................... & 52 \\
\hline 4.2 & Aspectos Econômicos de Dubai... & 54 \\
\hline 4.3 & A Evolução do Turismo em Dubai: Pioneirismo no Oriente.......... & 56 \\
\hline 4.4 & Brasil: Um país com Dimensões Continentais ........................ & 58 \\
\hline 4.5 & Histórico das Políticas do Turismo Brasileiro ............................ & 60 \\
\hline 4.6 & A Economia do Turismo no Brasil & 61 \\
\hline 4.7 & Análise dos Estudos de Caso á luz do Liberalismo .... & 63 \\
\hline Conclu & $+\ldots \ldots \ldots \ldots \ldots$ & 67 \\
\hline Refer & ias Bibliográficas... & 69 \\
\hline
\end{tabular}




\section{INTRODUÇÃO}

As primeiras viagens a Turismo, segundo alguns autores, dentre eles De La Torre, se deram na Grécia Antiga do século VIII a.C, com a locomoção de pessoas para assistir aos Jogos Olímpicos, a cada quatro anos $^{1}$. Desde então, tornou-se mais e mais evidente que os indivíduos estão submetidos a diversos tipos de restrições em seus deslocamentos físicos, seja para destinos domésticos ou internacionais. Essas limitações ferem propensões inatas ao ser humano, especialmente em sociedades complexas, como o desejo de conhecer outras realidades, descobrir coisas novas ou simplesmente lazer. De fato, o turismo tornou-se um escape à sedentarização progressiva do homem, anteriormente nômade. ${ }^{2}$

O advento da globalização, os avanços tecnológicos nos transportes e nas comunicações, o aumento das liberdades políticas e sociais e o progresso material acompanhado de uma melhor distribuição de renda que marcam a humanidade nos dias de hoje transformaram o turismo em uma atividade cada vez mais corriqueira. Após a Segunda Guerra Mundial, muitos destinos da Europa e do Pacífico que antes eram de total desconhecimento internacional foram incorporados às grandes rotas turísticas, graças à proliferação e ao barateamento da infra-estrutura de transportes. Para dar um exemplo, os aeroportos até então voltados ao uso militar, foram progressivamente aproveitados pela emergente indústria do turismo ${ }^{3}$.

Os benefícios do crescimento da atividade turística são inúmeros. O turismo propicia tanto o acesso quanto estímulos à preservação de patrimônios culturais, quanto promove interações sociais. Recentemente, ele vem promovendo uma maior consciência em relação às questões ambientais que ameaçam o futuro comum dos habitantes do planeta. E, mormente, o turismo tem um inequívoco significado econômico, haja vista que em muitos países esta atividade é das mais relevantes da economia.

No Brasil de hoje, o estudo do turismo é ainda muito insipiente, a despeito do número crescente de estudiosos e pesquisadores devotados à 
analise de suas dimensões. Aos poucos vai se tornando evidente que o turismo precisa ser analisado à luz de suas relações com outros fenômenos sociais e políticos, notadamente as regulações e políticas do setor, tanto nacionais quanto internacionais. Da mesma forma evidencia-se que o turismo pode (e deve) ser estudado como variável independente (causa) quanto dependente (efeito) de fenômenos a ele relacionados ${ }^{4}$.

A atividade turística pode ser afetada por condicionantes culturais, geográficas, políticas, econômicas e legais nos âmbitos nacional e internacional, sendo seu estudo essencialmente multidisciplinar ${ }^{5}$. Em sua vertente internacional, o turismo sofre influência de diversos fenômenos típicos do campo das relações internacionais. Os fluxos e as dinâmicas do Turismo internacional são influenciados pela natureza da política e do sistema internacional, assim como pela ação de diversos atores e agências internacionais. Destacam-se, neste particular, (i) as regras (instituições) e as políticas dos governos nacionais; (ii) as estratégias de empresas multinacionais; (iii) os parâmetros estabelecidos por organizações internacionais, como a OMT (Organização Mundial do Turismo), ou UNWTO (United Nations World Tourism Organization), e as ações de inúmeras organizações não-governamentais na institucionalização da área. Assim, fica clara a relação entre a expansão das atividades turísticas e a própria caracterização do fenômeno da mundialização ou globalização.

O turismo, enquanto fenômeno social e econômico, insere-se como objeto de estudo das relações internacionais também em razão da crescente amplitude e abrangência do escopo de preocupações dessa disciplina ${ }^{6}$. A renovação das abordagens teóricas propostas para as relações internacionais no Brasil, que prevê uma redefinição da centralidade conceitual da área situada exclusiva e repetidamente na relação entre Estados, se direciona a uma ampliação do estudo das relações internacionais ${ }^{7}$ e passa a englobar uma agenda mais ampla, em particular de atividades econômicas, onde se encaixa bem o turismo.

A pesquisa localiza-se na confluência dos campos de estudo das relações internacionais e do turismo. Pretende demonstrar como há uma 
forte inter-relação entre ambos - ou seja, como os fenômenos que caracterizam a atividade turística internacional podem ser mais bem compreendidos à luz das teorias e conceitos próprios das relações internacionais e, da mesma forma, como algumas dinâmicas deste último podem ser observadas e estudadas em maior profundidade e riqueza quando o foco recai sobre as atividades turísticas.

Neste sentido, a pesquisa visa compreender por que alguns governos nacionais atribuem maior importância à expansão do turismo internacional do que outros e como se expressa concretamente em termos de mudanças institucionais e políticas públicas. Para tanto, propõe-se uma comparação entre as iniciativas promovidas em anos recentes pelos governos do Brasil e de Dubai, o primeiro sendo caracterizado como um caso de baixa importância atribuída ao turismo internacional e o segundo como um caso paradigmático de sucesso. Enquanto Dubai, localizado em região até pouco tempo física e culturalmente inóspita para estrangeiros, vem superando quaisquer prognósticos, no que tange ao crescimento do número de visitantes estrangeiros, o Brasil, que é um país rico em recursos essenciais para atrair turistas do exterior, parece renegar tal vocação.

Por que os governos de alguns países incentivam o turismo, enquanto outros não o fazem, mesmo dispondo de reconhecidas vantagens comparativas no setor? Por que alguns pressupostos neoliberais aplicados nas duas localidades estudadas funcionaram bem para uma e a outra não obteve resultados a contento para o turismo? Qual seria o modelo de desenvolvimento, gestão e controle do turismo que poderia ser adotado, sabendo-se que as estruturas e os recursos governamentais destes países estão fragilizados?

Por meio de questões como estas, procurou-se observar como o fomento da atividade turística pode se encaixar dentre os principais pontos da política externa e contribuir para o fortalecimento do Balanço de Pagamentos (BdP) e do Produto Interno Bruto (PIB) de países em desenvolvimento como o Brasil, se espelhando em modelos bem sucedidos como Dubai. 
Para tanto, foram feitas analises dos dois casos específicos, Dubai e do Brasil, no âmbito internacional do turismo, destacando-se os campos social, cultural e, principalmente, no econômico, levando-se em consideração as devidas proporcionalidades e diferenças, de maneira que o estudo proporcione uma análise cruzada. Além disso, foi verificado se o caso de sucesso estudado poderia configurar-se como um modelo de desenvolvimento sustentável para o turismo de uma região menos beneficiada financeiramente e, a partir do estudo empírico, foram propostas interpretações e problematizações específicas.

Também fizeram parte do material consultado, arquivos, relatórios, artigos, pesquisas, publicações, entre outros documentos contendo sistemáticas, normas, planos e programas produzidos pelos mais diversos organismos e pessoas, bem como por meio da internet. Além de leitura e análise da literatura sobre os dois temas (pesquisa bibliográfica), assim como sobre os casos estudados.

Dubai, em menos de 20 anos, por meio da criação do DCTPB (Dubai Commerce and Tourism Promotion Board) em 1989, data esta que sugere a delimitação temporal deste trabalho até os dias atuais, tornou-se um grande centro comercial e uma das cidades mais visitadas por turistas, estejam eles interessados em compras, em divertimento, em cultura ou em negócios. Isso se deve ao modelo implantado e às políticas a este concernentes.

No Brasil, algumas atitudes isoladas vêm sendo tomadas nesse sentido há algum tempo, mas nada que seja efetivamente eficiente, como mostra o atual quadro da situação do setor do turismo do país e seu posicionamento na economia turística mundial.

O mundo todo passa a ter uma maior noção da importância econômica da atividade turística e, para tanto, entidades como a OMT, tornaram-se importantes protagonistas no cenário internacional. Ela pode ser considerada a prova mais concreta da crescente importância internacional do turismo.

Para a verificação deste fato, o estudo descreve o campo de estudo do turismo internacional, sua economia e sua institucionalização; aborda 
sobre as teorias das relações internacionais: Realismo, Liberalismo e Marxismo, além de destacar os principais pontos de confluência dos dois campos de estudo, tais como, meio ambiente, cultura, segurança, fluxos migratórios, direitos humanos, desenvolvimento e pobreza. As principais características sócio-econômicas, geográficas e históricas dos dois casos estudados são descritas, de maneira que se possibilite uma comparação à luz das teorias neoliberais.

Finalmente, este trabalho justifica-se pela influência que as relações internacionais têm sobre a dinâmica e o estudo do turismo, assim como, mesmo que em menor escala, a dinâmica do turismo tem sobre as relações internacionais. Apesar de não serem estudadas em conjunto de forma sistemática, turismo e relações internacionais são áreas que têm muito a ganhar com o desenvolvimento de abordagens conjuntas. 


\section{1 - O TURISMO INTERNACIONAL COMO OBJETO DE ESTUDO}

Tanto em razão de ser uma atividade sócio-econômica relativamente nova, quanto devido a seu caráter multidisciplinar, o campo do turismo caracteriza-se por uma evidente fragilidade no que concerne à sua própria delimitação. O turismo pode ser estudado por diversas perspectivas e disciplinas, dada a complexidade das relações entre os elementos que o formam ${ }^{8}$.

Sabe-se que a atividade turística pode promover a difusão dos valores culturais e sociais dos locais envolvidos na troca - país receptor e país emissor do turista; estimular atividades produtivas que se realizam pela soma de esforços de múltiplos atores sociais, econômicos e geográficos, o que se poderia chamar de desenvolvimento social; integrar socialmente e incrementar a consciência nacional; desenvolver a criatividade e o talento de indivíduos, empresas e associações civis e/ou profissionais em vários campos - cultura (arte, folclore, música, dança, culinária, etc.), lazer (esporte, meio ambiente), educação, ciência \& tecnologia, entre outros; promover o sentimento de liberdade mediante a abertura do mundo, por meio de contatos com outras culturas, ampliando, assim, o horizonte de indivíduos, entre outros benefícios.

Como se trata de uma atividade regulada no plano multilateral, é cabível a aplicação do conceito de turismo adotado pela própria agência representativa do turismo, a OMT, ligada a uma Organização Internacional (OI) de grande relevância para as relações internacionais, a ONU (Organização das Nações Unidas).

Um conceito de turismo, outrora adotado pela OMT era o desenvolvido por Oscar de La Torre (1992), apud Merigue (2003):

"O turismo é um fenômeno social que consiste no deslocamento voluntário e temporário de indivíduos ou grupos de pessoas que, fundamentalmente por motivos de recreação, descanso, cultura ou saúde, saem de seu local de residência habitual para outro, no qual 
não exercem nenhuma atividade lucrativa nem remunerada, gerando múltiplas inter-relações de importância social, econômica e cultural".

A OMT (2001) define hoje, que

"o turismo compreende as atividades realizadas pelas pessoas durante suas viagens e estadas em lugares diferentes do seu entorno habitual, por um período consecutivo inferior a um ano, por lazer, negócios ou outros",

Neste conceito, admite-se a existência do turismo de negócios, o que, para este trabalho, é muito importante, haja vista que esta é a principal modalidade do turismo realizado em uma das localidades estudadas: Dubai.

Esta definição também chama a atenção para características marcantes da atividade turística que são: a motivação da viagem, a limitação do tempo e a localização da atividade. Dada a singularidade da atividade turística, a inter-relação destas características deve ser considerada sistematicamente, formando o chamado Sistema Turístico - Sistur. Nele quatro elementos são observados: a demanda, formada por um conjunto de consumidores dos serviços turísticos; a oferta, composta pelos produtos, serviços e organizações envolvidas na atividade; o espaço geográfico, que é a base física onde tem lugar o encontro entre a oferta e a demanda e os operadores de mercado, que são as empresas e organismos, cuja principal função é facilitar a inter-relação entre a oferta e a demanda.

\section{1 - O Turismo Internacional}

O turismo internacional é definido pela OMT como sendo uma atividade em que 0 viajante necessariamente cruza as fronteiras internacionais. Assim sendo, ele surge com as freqüentes viagens de comerciantes entre os mais diversos países. Ainda segundo a OMT (2001), sua evolução registrou um crescimento ininterrupto ao longo do tempo, tendo momentos de aumento em picos econômicos e momentos de moderação em períodos de recessão, o que claramente atrela a atividade turística ao ciclo econômico dos negócios. 
A evolução do mercado turístico, com base no número de turistas internacionais, segundo dados da OMT (2001), pode ser facilmente comprovada. No período de 1950 a 1980, o número de viagens internacionais duplicou a cada 10 anos. A partir de então, ele alcançou uma maior maturidade, demonstrando um crescimento mais lento pelo excesso de oferta. No início da década seguinte, o turismo apresentou um elevado grau de resistência às flutuações econômicas, sendo que de 1991 a 1993, devido à Guerra do Golfo, os países industrializados apresentaram uma diminuição nas taxas de crescimento do turismo; na atualidade, novos produtos são lançados e novas regiões começam a se consolidar como pólos turísticos, aumentando o leque de opções, a concorrência, dentre outros elementos.

Essa evolução pode ser demonstrada quantitativamente, ainda segundo dados da OMT. O número de chegadas de turistas internacionais a seus destinos em 1950 foi de 25 milhões e em 1996 foi de 595 milhões, demonstrando um crescimento médio de 6,5\%.

Em 1996 o turismo internacional representou 10,7\% do Produto Interno Bruto mundial e empregou 255 milhões de pessoas, fator este que destaca a importância social e econômica do setor.

\section{2 - O Turismo como Atividade Econômica}

Conforme Bursztyn (2003),

"[a] atividade turística tal como nós a entendemos hoje pressupõe a moderna sociedade capitalista. Foi somente no início do século $X X$ que, a partir da escala de acumulação e do desenvolvimento de novas tecnologias, tornou-se possível o surgimento de uma elite disposta a gastar dinheiro em turismo e viagens a lazer".

A economia foi a primeira disciplina a se interessar pelo turismo, visto que nas primeiras décadas desse século, percebeu-se, na Europa, que o turismo era grande fonte de divisas, desempenhando um importante papel nos fluxos comerciais e monetários entre as nações ${ }^{9}$. 
O conceito de 'gastos turísticos' permite identificar diferentes categorias de oferta turística, conforme o local em que se realize o gasto. Segundo Joaquim de Andrade et al (2008), o turismo não existiria sem os setores que o compõem, que é onde ocorrem os gastos. São eles os estabelecimentos de serviços de alimentação; os de serviços de recreação, culturais e esportivos; transportes terrestres, marítimos e aéreos; estabelecimentos para alojamento; agências de viagem; agências de exploração de atrativos turísticos; lojas do ramo, entre outros. Este é o motivo pelo qual as mensurações e estatísticas deste setor se mostram tão incertas, já que estes serviços muitas vezes são utilizados pela população local.

Sendo assim, o turismo se qualifica como uma atividade pertencente ao chamado terceiro setor da economia, onde o produto a ser negociado consiste no deslocamento de pessoas, o que será revertido em gastos e receitas. Estes gastos têm continuidade na aquisição dos atrativos turísticos, na utilização dos meios de transporte, hospedagem, alimentação, compras, serviços de recreação e entretenimento e termina na fruição do roteiro ${ }^{10}$.

Barreto (2000) alega que

"O turismo internacional traz habitantes temporários ao país receptor, cujo efeito no sistema monetário traduz-se em ingresso de moeda estrangeira (divisas) e em arrecadação de impostos especiais para estrangeiros (vistos e capital inicial) (...). A aquisição de bens pelos turistas é um tipo de exportação, por isso, o turismo é chamado de exportação invisível".

A OMT (2001) também considera que a atividade turística seja a 'exportação' de uma região, nação, lugar ou destino e isso ajuda a equilibrar a balança de pagamentos, favorece a criação de empregos, a entrada de divisas no país, aumenta a arrecadação de impostos públicos e aquece a atividade empresarial, além de contribuir para a geração de Valor Agregado Bruto (VAB) na região receptora.

Segundo a OMT (2003), o turismo, hoje, representa a maior parcela das exportações mundiais dentre todos os setores, exceto o do petróleo e 
derivados e o de automóveis, peças e acessórios. Seu gasto é três vezes maior que os gastos mundiais com defesa.

A geração de divisas provenientes do turismo internacional é um fator relevante que deve ser apreciado pelas políticas de ajustes na Balança de Pagamento, como fonte geradora de superávit cambial ${ }^{11}$. A receita cambial turística no mundo em 1997 era de 436 bilhões de dólares e em 2006 passou para 732,8 bilhões de dólares, sendo que o fluxo receptivo internacional no último período é de 845,5 milhões de chegadas. A do Brasil em 1997 era de 1,1 bilhões de dólares e em 2006 foi para 4,3 bilhões de dólares em 2006 e o fluxo receptivo internacional no último período foi de 5 milhões de chagadas.

A WTTC (World Travel and Tourism Council) estima que o turismo cresça a uma média de 3\% em 2008, gerando 238 milhões de empregos e contribui com 9.9\% do PIB em escala global. Há que se considerar que esta entidade emprega em suas análises, uma metodologia otimista, em que são inclusas no trade turístico, desde o café da esquina às companhias aéreas e grandes cadeias hoteleiras, podendo gerar disparidades.

Os dados mostram as vantagens que o turismo pode proporcionar à economia de um país, principalmente aos países emergentes, como é o caso do Brasil. Reforçam, ainda, que a participação do turismo brasileiro na economia mundial, apesar de sua evolução nos últimos anos, não apresenta ainda crescimento significativo, quando comparado ao restante do mundo, principalmente com relação à Dubai, que dispõe de um produto turístico artificial e que será mais bem detalhado no quarto capítulo.

Segundo Tribe, os principais fatores macroeconômicos que afetam os custos dos produtos do turismo são: taxas de juros, que afetam o dispêndio e o investimento dos consumidores, além dos custos das empresas em empréstimos e etc; a inflação, que provoca queda na competitividade internacional para o mercado de exportação e para os países que contam com o turismo; taxa de câmbio, que influenciam os preços dos componentes das operadoras de turismo e os impostos indiretos, que são pagos a terceiros no varejo e têm efeito direto sobre os preços. 
Como qualquer outra atividade, a economia do turismo também é influenciada pela oferta e pela demanda. Porém o espaço geográfico e os operadores de mercado também influenciam de maneira decisiva.

A demanda turística, que é formada por um conjunto de consumidores de bens e serviços turísticos, determina a forma de turismo: doméstico ou internacional. Esse é caracterizado pela viagem de uma pessoa para um país diferente daquele em que reside. Aquele é identificado quando se viaja para um lugar dentro de seu país de residência, mas diferente de seu entorno habitual.

A oferta turística é definida pela OMT (2003) como

"o conjunto de produtos turísticos e serviços postos à disposição do usuário turístico, num determinado destino para seu desfrute e consumo".

Deve-se levar em consideração que a oferta turística nem sempre é utilizada apenas pelos turistas, mas também pelos residentes, implicando possíveis disparidades em levantamentos estatísticos para o setor.

\section{3 - O Contexto Internacional e a Institucionalização do Turismo}

Quando se fala em institucionalização, deve-se ter em mente que há uma interligação entre as diversas atividades que a economia envolve, pois a institucionalização de certos setores pode levar ao desencadeamento da institucionalização de outros setores. Para tanto, Becker (2001) expõe que a massificação de padrões de consumo que o Welfare State veio a abrir nos países capitalistas centrais e que apoiou-se na regulamentação do trabalho e na limitação do seu tempo; nas férias remuneradas;na aposentadoria; na legislação social; bem como nos novos horizontes de possibilidades abertos com a incorporação do avião à sociedade, levou ao estabelecimento do turismo. Isso fez com que os Estados tivessem de se adaptar às novas instituições, assim como se beneficiassem com os frutos do turismo.

O Papel do Estado em matéria de planejamento turístico desenvolvese fundamentalmente por meio das políticas do turismo. No entanto, os 
problemas no processo de desenvolvimento turístico não surgem unicamente dentro desse âmbito de atuação, os interesses privados também entram em jogo. Por isso, faz-se necessária a coordenação e cooperação entre as atividades da própria administração e suas empresas públicas com as empresas privadas do setor, bem como as organizações governamentais e não-governamentais ou voluntárias ${ }^{12}$.

"Essas organizações, cujo objetivo é a criação de redes e recursos comuns em favor da obtenção de ações coordenadas e economias de escala, apresentam uma ação coletiva em muitos campos do desenvolvimento turístico. Assim, proporcionam fontes de informação e dados para conhecer a realidade turística em muitos países. Igualmente proporcionam assistência direta àqueles países com demandas"13.

Os deslocamentos ligados às atividades políticas, econômicas e culturais passam a ter uma maior participação nas correntes turísticas como conseqüência da internacionalização e da interdependência entre países ${ }^{14}$. Isso acarreta uma pluralização da atividade, que ocorre com a participação de atores transnacionais, os quais estão diretamente ligados ao processo de integração. Esse processo é iniciado pelas ligações funcionais, colaboração militar, comércio, migração e turismo. Assim os esforços passam a ser direcionados para a sua institucionalização, preservando e protegendo a integridade comunitária ${ }^{15}$.

As instituições são grupos de regras, formais e informais, persistentemente conectadas que prescrevem o comportamento, constrangem as atividades e definem as expectativas ${ }^{16}$. A institucionalização do turismo é cada vez mais visível, se iniciando com a formação da UNWTO $^{17}$, guiada pelo Global Code of Ethics ${ }^{18}$.

A OMT (2001) enumera as Organizações Intergovernamentais com competência em turismo como segue:

1. Organização das Nações Unidas (ONU) - em agosto de 1963, na Conferência de Roma (Conferência das Nações Unidas sobre o turismo e as Viagens Internacionais), admitiu ser o turismo, um 
esforço importante no desenvolvimento dos países e estabelece fundos especiais (PNUD) para a assistência técnica em turismo. Lidera alguns programas na Mauritânia, Costa do Marfim, Sri Lanka, Turquia, Bolívia, etc.

2. Banco Internacional para a Reconstrução e o Desenvolvimento Dirigiu alguns projetos turísticos na África, Oriente Médio e América Latina.

3. Conferência das Nações Unidas sobre Comércio e Desenvolvimento (UNCTAD) - fundada em 1964, visando o desenvolvimento do comércio internacional e interessada no fenômeno turístico como instrumento de desenvolvimento. Por isso, o tema figura permanentemente na ordem do dia das seis comissões existentes.

4. Organização Internacional do Trabalho (OIT) - Desde 1965, mantém reuniões periódicas sobre as condições de trabalho no setor hoteleiro e de alimentação. Adotou uma resolução concernente ao desenvolvimento do turismo e das indústrias conexas num programa de assistência técnica e consultoria com a ONU e, a partir daí, editou vários documentos interessantes sobre o tema.

5. Organização das Nações Unidas para a Educação, a Ciência e a Cultura (UNESCO) - Fundada em 1945, realizou grandes programas para a reconstrução dos patrimônios culturais das nações. É, portanto, um organismo que exerce um papel muito importante no desenvolvimento do turismo cultural e afirma que "o turismo ajuda a preservar as identidades culturais dos países".

6. Organização Mundial do Turismo (OMT) ou UNWTO - Criada em 1970, para substituir a IUOTO (International Union of Official Travel Organisations). Ela é a agência especializada das Nações Unidas, que atua como um fórum global para assuntos institucionais e fonte de know-how sobre o turismo mundial e possui 154 países membros $^{19}$. 
Esta última promoveu em 2007 a Second International Conference on Climate Change and Tourism, que levou à Declaração de Davos (Suíça), que por sua vez foi submetida ao Tourism Ministerial Summit on Climate Change, ocorrido em conjunto com a Assembléia Geral da UNWTO ${ }^{20}$, além de diversos outros encontros no setor, dentre diversas conferências no setor.

A UNESCO também tem grande participação na institucionalização do setor, pois a interpretação da assinatura de um tratado internacional relacionado ao Patrimônio Cultural e Natural da Humanidade, adotado em 1972, que se mostra eficiente no que tange a essa preservação ${ }^{21}$, trabalha de forma integrada à biodiversidade, à cultura e à história, criando atrativos para compor a cadeia de produção turística, assim como protegendo-os da degradação.

A OMT (2001) também destaca algumas Organizações Intergovernamentais regionais com competência em turismo. São elas:

1. Organização para a Cooperação e o Desenvolvimento Econômico (OCDE) - Em 1949, um ano depois de usa criação, constituiu uma comissão de turismo com a finalidade de identificar os recursos e divisas suscetíveis de oferecer apoio para a reconstrução das economias européias, entre outras ações relacionadas à atividade.

2. Conselho da Europa - Dentre as conexões desta instituição com o turismo está na constituição de um organismo para a proteção dos territórios e o estabelecimento de recomendações sobre o desenvolvimento turístico nas regiões montanhosas, além do intercâmbio turístico nos países da Europa Central.

3. Comunidade Européia (CE) - Em 1986 recomendou aos países membros para simplificar os trâmites para a livre circulação, adotou medidas relativas à segurança dos hotéis e à informação dos clientes. Também promoveu concessão de linhas de créditos do Fundo Europeu de Desenvolvimento Regional, entre outras medidas.

Dentre as Organizações Não-Governamentais especializadas em turismo listadas pela OMT destacam-se as seguintes: 
1. Associação de Transportes Aéreos Internacionais (IATA)

2. Associação Internacional de Hotelaria (AlH)

3. Federação Internacional de Operadoras de Turismo (IFTO)

4. Federação Internacional de Albergues de Viagens (IYHF)

5. Conselho Mundial de Turismo (WTTC) - É um fórum de líderes dos negócios no setor de viagens e turismo que visa desenvolver uma consciência de que estas atividades fazem parte de uma das maiores indústrias do mundo ${ }^{22}$, a chamada "indústria sem chaminé". Promove a execução de pesquisas, encontros e outros meios que possibilitem o fomento e a profissionalização desta atividade.

Estima-se que US\$ 2 bilhões são gastos por dia em turismo internacional em todo o mundo. Assim, a atividade turística também passa a ser considerada no âmbito da OMC (Organização Mundial do Comércio), cuja preocupação, dentro do escopo do turismo, é encontrar a melhor forma de sua liberalização no contexto do GATS (General Agreement on Trade in Services), vigente desde 1995, ficando clara a relevância do turismo no comércio internacional, através da implementação de regras comuns aos países $^{23}$.

A grande quantidade e a qualidade de instituições intergovernamentais existentes, tanto em nível regional, quanto global e até mesmo de ONGs ligadas ao setor, além do fato de o turismo internacional configurar-se como uma importante atividade econômica em muitos países, promovendo inter-relações entre eles, deixa claro o caráter internacionalista que a atividade assumiu nos últimos tempos.

Dado o constante envolvimento de Estados e outros atores nãoestatais nessa atividade, fica confirmada a forte dependência do turismo com relação às decisões tomadas pelos atores internacionais envolvidos, assim como às teorias e os temas da agenda das relações internacionais, se fazendo necessário um estudo conjunto dos dois campos. 


\section{2 - TEORIAS DAS RELAÇÕES INTERNACIONAIS}

A busca do conhecimento sempre foi uma constante na história da humanidade. No campo internacional, devido à necessidade de as sociedades analisarem as realidades externas que as afetam, sociedades estas que estabelecem entre si, trocas e contatos constantes das mais variadas naturezas e alcances. Surge assim, a disciplina das relações internacionais.

Consorte Sarfati (2003), as relações internacionais nasceram

“(...) tentando responder a questões como: quais as causas das guerras? Como preveni-las? Como alcançar a paz? Dessa forma, desde o início, os estudiosos do nosso campo se digladiaram com questões de segurança e cooperação internacionais, ou seja, de como os Estados se protegem de ameaças externas e como poderiam ter evitado que os conflitos se transformassem em guerra."

Pecequilo (2004) acrescenta que a preocupação dessa nova disciplina é focada

"no cenário externo, no qual estão inseridas as sociedades, buscando desvendar os desenvolvimentos que se processam neste meio específico, visando o seu entendimento, compreensão e também mudança. As guerras, a paz, a diplomacia, as interações econômicas e culturais entre diferentes povos, os fluxos naturais, as comunicações são alguns dos elementos que compõem a esfera do internacional e que têm implicações e efeitos sobre os homens. Trata-se, com isso, do estudo e análise direcionada e específica do internacional, de suas formações e interações sociais, fornecendo uma estrutura coesa e clara de pensamentos."

Desta maneira, os pensadores das relações internacionais passaram a desenvolver conceitos e teorias, que consistem no instrumental de análise e estudos de como funciona o sistema internacional, os atores que dele fazem parte e os fenômenos provenientes das interações entre eles. 
Segundo Sarfati (2003), essas teorias vêm sendo elaboradas desde 1919, sobretudo a partir da década de 1970, por meio de debates entre os pensadores e até hoje este processo está em curso. Diferentemente das ciências naturais, as relações internacionais devem ser observadas ao longo da história e a interpretação desta atinge um campo muito mais amplo de entendimentos que invariavelmente refletem as tradições epistemológicas distintas e composições ontológicas bastante diversas.

O sistema internacional, de acordo com Marcel Merle, apud Pecequilo (2004), é um

"meio onde se processam as relações entre os diferentes atores que compõem e fazem parte do conjunto das interações sociais que se processam na esfera do internacional, envolvendo seus atores, acontecimentos e fenômenos."

Ainda segundo a autora, os atores internacionais foram surgindo ao longo dos séculos, através e conforme a necessidade do contexto histórico. Estes são os Estados, que surgiram em 1648, com a assinatura do Tratado de Vestfália, juntamente com seus princípios da soberania, autonomia e território; as organizações internacionais (Ols), que vieram a se firmar no pós-1945, juntamente com as forças transnacionais (FTs), compostas por organizações não-governamentais (ONGs), empresas transnacionais (ETNs), grupos diversos e a opinião pública internacional. Cada um deles possui diferentes capacidades, carateres, recursos, objetivos e interesses. Suas ações e interações definirão o perfil da sociedade internacional.

Já as correntes de pensamento desta disciplina, ou seja, as teorias das relações internacionais, seguem o eixo da cooperação ou o do conflito. As clássicas dividem-se em Realismo, Liberalismo e Marxismo e serão debatidas a seguir. Existem ainda subdivisões dentro destas, debates metodológicos e teorias de economia política, que poderão ser mencionadas ao longo do trabalho. Estes pontos abordam diferentes variáveis políticas, diplomáticas, sociais, culturais e econômicas de seus atores, fenômenos e acontecimentos e são formas de pensar a realidade internacional, tanto as antigas, quanto as modernas (Hoffman, apud Pecequilo, 2004). 


\section{1- Realismo}

O realismo ainda é a corrente teórica dominante nas relações internacionais. Sua elaboração teve início no século $X X$, a partir dos trabalhos de E.H.Carr (Vinte anos de crise) e Hans Morguenthau (A política entre as nações). No entanto, foi originada a partir do trabalho de Trucídides (História da Guerra do Peloponeso) onde ele analisa as origens, dinâmicas e motivações do relacionamento entre Atenas e Esparta, na Grécia Antiga. Esta é a origem do princípio do equilíbrio de poder, que configura o tipo ideal no cenário europeu dos séculos XVII a XIX e que foi organizado a partir do Congresso de Viena, em 1815. Mais tarde, Maquiavel e Thomas Hobbes enfatizam o aspecto competitivo, conflituoso, ambicioso e predatório da vida humana (Pecequilo, 2004).

A autora complementa que, é nesta corrente, que surge o termo high politics. Pode-se dizer que este indique os aspectos mais 'nobres' da política internacional, que seriam os elementos militares, diplomáticos e estratégicos, os quais definem a capacidade de projeção internacional do Estado. Em contrapartida, a low politics trata das questões sociais, culturais e econômicas.

Foi a partir de problemáticas como a integração, interdependência e transnacionalização, focadas pela low politics, que o teórico Kenneth Waltz, na década de 1970, formulou o Neo-Realismo ou Realismo Estrutural. Este oferece abordagens mais científicas para o estudo da política internacional, se contrapondo ao liberalismo, que ganhava cada vez mais espaço. Segundo este teórico, os Estados não agem somente para maximizar seu poder, em nome do interesse nacional em termos de poder, mas também para assegurar a sua posição e capacidade dentro do sistema em relação aos demais Estados.

Em suma, Percequilo (2004) destaca que os pressupostos básicos do realismo são como segue: A natureza humana como sendo má, perversa, incontrolável e ambiciosa e que os homens sempre buscam a realização de seus interesses individuais. O sistema internacional sendo formado por 
Estados soberanos que interagem sem controle ou lei superior - anarquia -, assim como a possibilidade latente de guerra. Os Estados como sendo os únicos atores internacionais reconhecidos pela corrente, não importando os demais. A ordem do sistema internacional como sendo o equilíbrio de poder e os conceitos centrais como sendo a anarquia, o poder e o interesse nacional, o Estado e o equilíbrio de poder.

\section{2- Liberalismo}

O liberalismo clássico surge nos séculos XVII e XVIII, com as chamadas Revoluções Liberais, dentre elas a Revolução Francesa de 1789, influenciadas pela nova e mais importante classe social do Estado liberal moderno, a burguesia, juntamente com o declínio do absolutismo. Dentre seus principais autores estão John Locke, que argumenta que o Estado existe para garantir a liberdade de seus cidadãos e Jeremy Bentham, que cunhou o termo 'direito internacional'24, no campo político, enquanto no econômico, destaca-se Adam Smith.

Esta corrente sustenta que o progresso das sociedades se dá a partir dos indivíduos, que deverão ter asseguradas as condições legais e legítimas para alcançar este progresso. O Estado estruturará os intercâmbios domésticos e regerá as relações humanas, a partir de um pacto coletivo. Doyle defende a primazia dos atores sociais, a qual prega que

“(...) os atores fundamentais das relações internacionais são os indivíduos e os grupos privados que se relacionam de forma racional e, portanto, são avessos a riscos e tendem a se organizar de forma coletiva, a fim de promover os seus interesses ante a sociedade".

Immanuel Kant, apud Sarfati (2003), teórico do liberalismo pacifista, cujas idéias estão baseadas em dois pilares, republicanismo democrático e união dos Estados liberais por meio de uma federação, defende que estes Estados (democráticos) não fazem guerra entre si, já que há uma interdependência, marcada, principalmente por preferências estatais 
convergentes. Assim, a concepção de poder para estes teóricos está baseada na

"disposição dos Estados em gastar os seus recursos ou realizar concessões em função de suas preferências, ou seja, trata-se de uma concepção essencialmente voltada à barganha ou à negociação".

Percequilo (2004) defende que foi a partir do Idealismo wilsoniano que surgiu a Liga das Nações, o embrião da ONU, estabelecida a partir do Tratado de Versalhes em 1919, onde as potências vencedoras da Primeira Guerra Mundial se reuniram para negociar um acordo de paz. A Liga seguia o princípio básico da segurança coletiva e tinha como objetivo promover arranjos multilaterais através dos quais os seus quarenta e quatro Estadosmembros compartilhariam decisões e ações, sob a liderança de um hegemon.

Originalmente formulada por Charles Kindleberger em 1973, apud Percequilo (2004), a Teoria da Estabilidade Hegemônica defende que

"a ordem econômica liberal do sistema internacional é função da existência de uma potência hegemônica, que se torna responsável pela sua criação, condução e administração, a partir da posse de diversos elementos concretos de poder: matéria-prima, capital, mercado e tecnologia".

Posteriormente, autores como Robert Keohane, incluíram em suas análises a importância da ideologia e da política para a sustentação da ordem mundial. Combinados os dois autores, tem-se que ela deve ser sustentada por recursos de poder em três categorias: estrutural, institucional e situacional. Este último teórico defendia, no pós-guerra em 1945, juntamente com Joseph Nye, que o desenvolvimento das instituições e regimes internacionais, de iniciativa norte-americana, permitiu 0 aprofundamento de estruturas e mecanismos de cooperação entre os Estados.

Um destes mecanismos são os regimes internacionais. A despeito destes, Krasner, apud Jackson e Sorensen (2007) formulou que 
“(...) regimes são conjuntos de princípios, normas, regras e procedimentos de tomada de decisão implícitos e explícitos em torno dos quais as expectativas dos atores convergem em uma determinada área das relações internacionais e fornecem as estruturas nas quais as relações entre os Estados podem se organizar de maneira mais completa e equilibrada".

Desta maneira, o liberalismo promove a ampliação da agenda internacional, destacando a importância da low politics no contexto internacional e sua influência na interação entre os atores internacionais. Ocorre, então, a evolução da natureza do poder, cujas formas extrapolam as tradicionais do Hard Power. Este está relacionado a recursos tais como o tamanho e a geografia de um país; sua localização e a natureza de suas fronteiras; população; organização interna e estabilidade; patriotismo; preparação militar; recursos naturais e capacidade industrial, abrindo espaço também ao Soft Power, o qual sustenta-se em elementos como o poder de convencimento e as idéias; o desenvolvimento econômico; o conhecimento; a tecnologia; a ideologia e a cultura, segundo descrição de Percequilo (2004).

Resumindo, para a autora, na corrente liberal, os homens são naturalmente bons, cooperativos e pacíficos. O sistema internacional, assim como no realismo é anárquico, porém com a cooperação latente, sendo que a desordem pode ser controlada por meio dos mecanismos corretos, além de privilegiar a liberdade, a igualdade e a individualidade, através de leis e canais cooperativos. Os Estados são os principais atores, porém acompanhados pela crescente importância dos demais. A ordem do sistema internacional é tomada pela cooperação alcançando-se os conceitos de governança global, além dos de cooperação, regimes internacionais, forças transnacionais, interdependência e transnacionalização. 


\section{3 - Marxismo}

Tal qual o nome indica, o idealizador desta corrente foi Karl Marx. No entanto, segundo Percequilo (2004), este pensador não o fez com o intuito de construir uma teoria das relações internacionais, mas veio a se torná-lo, devido a sua abrangência contextual.

"[O] marxismo nasce em sua forma clássica em meados do século XIX, englobando reflexões políticas, sociais, históricas, filosóficas e econômicas."

É com a obra deste pensador, elaborada em conjunto com Friedrich Engels (O manifesto comunista) que ele ganha espaço a partir do século $X X$, em oposição ao liberalismo econômico. À época, a economia consolidava um sistema internacional, permitindo a observação de novos fenômenos. Além de dedicar-se a explicar esta realidade, ele propunha transformações.

A partir das análises destes fenômenos, diversos países da Europa Oriental, da Ásia e até mesmo da América Latina, passaram a basear suas estruturas sociais e políticas nas premissas desta teoria, quando do surgimento da classe operária que teve origem na Revolução Industrial. Tais mudanças culminaram na Revolução Russa em 1917, a qual deu início ao bloco soviético no pós-Segunda Guerra Mundial e na Revolução Chinesa em 1949, ainda segundo a autora.

Esta corrente teórica sustenta-se em quatro temas principais: a determinação material, que se preocupa com a economia, o modo de produção e os objetivos desta produção (solidariedade, sobrevivência ou lucro), os quais definirão como a sociedade está organizada; a determinação histórica, a qual estabelece que a história passada influencia o comportamento presente, devendo ser modificada, caso seja desejado, através de sua dimensão evolutiva que necessariamente culmina em revoluções; a centralidade das classes, que determina que as classes são os principais agentes da vida política e internacional e que ocasionais conflitos ocorrem e, por fim, a revolução, que surge através dos conflitos, pressuposto este de encaminhamento normal, advindo de antagonismos sociais. 
Percequilo (2004) resume esta corrente da seguinte forma. A natureza humana para o marxismo é naturalmente boa, porém, sofrendo opressão, é levada à revolução. O sistema internacional é formado por Estados e povoado por atores não-estatais determinados economicamente, com o domínio da classe burguesa, porém seu desaparecimento levaria à internacionalização da revolução proletária. Os atores são as classes sociais: burguesia e proletariado, os quais determinam a estrutura, através de suas expressões. A ordem do sistema internacional é construída segundo interesses de classe e sofre transformações através da revolução, surgindo uma nova realidade.

Em suma, a relevância do debate entre as correntes apresentadas neste capítulo é incontestável para as relações internacionais. No entanto, há que se levar em consideração, também, que a complexidade dos acontecimentos internacionais, a evolução das tecnologias e o crescente número de atores internacionais, fizeram com que novos, ou mesmo uma releitura de temas tradicionais, que concernem a esta disciplina, emergissem com o passar do tempo e que estes também se tornassem importantes para a ordem e o sistema internacional, de maneira que serão tratados de forma separada, como pode ser conferido no capítulo que segue. 


\section{3 - A CONFLUÊNCIA DE CAMPOS DE ESTUDO: RELAÇÕES INTERNACIONAIS E TURISMO}

A movimentação das pessoas, dinâmica intrínseca à atividade turística, pode influenciar ou ser influenciada por diversos fatores do cenário internacional. Essas influências podem ser de natureza social, econômica, cultural ou política, cujas conseqüências serão negativas ou positivas à atividade turística e à localidade que a emprega.

Mais e mais, essa movimentação de pessoas é composta por fluxos de turistas estrangeiros, promovendo um intercâmbio destes entre os países. Então, quando dois ou mais países são envolvidos neste tipo de relação, fala-se em turismo internacional. Há que se considerar que nessa modalidade de turismo, eventos no âmbito internacional são muito constantes, razão esta que procura relacionar o campo do turismo ao campo das relações internacionais.

Com o passar do tempo, os temas e agendas das relações internacionais tornaram-se cada vez mais amplos, em virtude da influência dos diferentes acontecimentos que se processam no sistema internacional. Eles passam a influenciar questões também relevantes à atividade turística, as quais devem ser levadas em consideração pelos estudiosos dos dois campos, haja vista a natureza transnacional da atividade, quando estudada no seu âmbito internacional. São elas: meio ambiente; segurança, terrorismo e guerras; fluxos migratórios; cultura; direitos humanos e desenvolvimento e combate à pobreza.

\section{1 - Meio Ambiente}

De acordo com Becker (2001), as mudanças no atual modo de produzir promovem a destruição progressiva do meio ambiente. A natureza perde seu significado antigo para se transformar em capital de realização atual ou futura. Essa valorização da natureza como mercadoria também acontece na exploração da atividade turística. 
Segundo Barros-Platiau et al ${ }^{25}$, em seu artigo 'Meio ambiente e relações internacionais' Isso também foi

"demonstrado por vários economistas, como Ezra Mishan e Arthur Pigou, por exemplo, que o crescimento econômico, especialmente quando refletido pelo Produto Interno Bruto (PIB), não era capaz de contabilizar determinados custos oriundos do consumo e produção, as chamadas 'externalidades negativas"'.

Segundo Barros-Platiau (2006), a primeira discussão no âmbito das Nações Unidas sobre o assunto foi a Conferência das Nações Unidas sobre o Meio Ambiente Humano (CNUMAH), realizado em Estocolmo em 1972 e, a partir desta houve uma evolução tremenda. Contudo, o que parece ter dado o real primeiro estímulo nesta área foi a Conferência das Nações Unidas sobre Meio Ambiente e Desenvolvimento (CNUMAD), promovido no Rio de Janeiro em 1992, que contou com uma maior participação de atores internacionais. Desde então, este se tornou um debate freqüente no meio internacional. A pesquisadora coloca que

"Entre 1990 e 2004, houve uma mudança conceitual essencial para a política ambiental global, marcada pela consagração do conceito de Desenvolvimento Sustentável e pelo reconhecimento formal da necessidade de cooperação internacional para a sua efetiva incorporação nos processos decisórios nacionais" ${ }^{\text {"26 }}$

Ainda de acordo com a pesquisadora, a crescente regulação das relações internacionais em matéria ambiental, que promoveu uma verdadeira positivação de costumes e normas e que acompanham a evolução do direito internacional público, permitiu que os conceitos de governança global, abordagens organizacionais e de regimes internacionais - as três abordagens mais comuns pra a analisar o problema da gestão ambiental - ocupassem um lugar privilegiado na agenda internacional contemporânea. Assim, surgiu a

"necessidade de gestão coletiva da crise ambiental, uma vez que os problemas que constituem esta crise perpassam as tradicionais 
fronteiras territoriais dos Estados nacionais e demandam uma ação conjunta de todos os atores envolvidos."

A autora ${ }^{27}$ complementa, ainda, que

"Marie-Claude Smouts sugere que tais abordagens representam de fato o movimento da cooperação internacional desde a instituição do sistema internacional Vestfaliano no século XVII rumo a uma possível governança mundial."

Para o Turismo, fica clara a ambigüidade que sua combinação com o tema meio ambiente representa, pois assim como o turismo pode promover a conscientização ambiental, tanto de visitantes quanto de trabalhadores envolvidos nesta atividade, o meio ambiente também pode assumir a posição de alvo de degradação, através de abusos por parte destas mesmas pessoas, ao se tornar um atrativo turístico, implicando sua saturação e provável degradação.

A exemplo deste último caso, a OMT (2001) destaca o que acontece atualmente no Mediterrâneo, onde a afluência dos visitantes e a rápida urbanização da costa têm dado lugar à superexploração dos entornos, bem como à destruição de espaços de grande valor paisagístico.

Em contrapartida, a organização também menciona que os governos do bloco europeu, por exemplo, têm contribuído muito para a conscientização ambiental da população, dado a denúncias de especialistas e pressões procedentes dos meios de comunicação e legislações atualizadas. Assim, diversas empresas do setor turístico têm aderido ao "movimento verde". Através desse, elas descobriram que podem obter maiores lucros, pois esse movimento melhora a eficiência nos custos dos processos, além de contribuir para sua imagem perante o público-alvo.

$\mathrm{O}$ artigo do site greenbuildings.com, que discute sobre o "movimento verde" na hospitalidade, cita exemplos disso. São eles: a economia de água e energia através do encorajamento de hóspedes a serem mais energeticamente eficientes, por meio do reaproveitamento de roupas de cama e banho, do uso racional de ares condicionados e luzes; a diminuição 
de lixo, seu reuso e reciclagem e o emprego de designs de prédios mais sustentáveis.

É destacado, ainda, neste artigo, que o conceito de sustentabilidade foi, pela primeira vez, mencionado numa plataforma internacional coordenada, em 1987, no artigo "Our Common Future" da Comissão de Brundtland, patrocinado pela ONU. Foi assim que o movimento em direção à sustentabilidade se espalhou pelo mundo.

Advindo do

"conceito de desenvolvimento sustentável, que é a capacidade de se satisfazer às necessidades atuais, sem por em perigo a capacidade das gerações futuras para satisfazerem suas próprias necessidades, o conceito de Turismo Sustentável tem a pretensão de compatibilizar o desenvolvimento turístico e a conservação dos recursos por ele explorados" (OMT 2003).

Infelizmente, estes conceitos e práticas podem não ser viáveis para a maioria dos países em desenvolvimento, pois uma das prioridades destes governos é a elevação do seu nível de vida, bem como o seu desenvolvimento econômico. O turismo está quase sempre baseado na exploração dos recursos naturais, já que se trata de uma atividade rentável, que pode gerar certo nível de renda e emprego para sua população. Benefícios tão rápidos dificilmente seriam gerados por meio de outras atividades econômicas, que geralmente exigem maiores investimentos.

Os fenômenos naturais também fazem parte do fator meio ambiente e podem ser diretamente afetados pelas mudanças climáticas. O verão da Europa, por exemplo, atraí milhões de turistas todos os anos devido às temperaturas quentes. Mas este mesmo fator pode causar o processo inverso, como foi o caso do verão de 2008 na Grécia, onde um incêndio, causado pela estiagem, acarretou a retirada, pelo governo, de turistas dos hotéis localizados nas áreas de risco.

No caso de Dubai, as mudanças climáticas podem ser extremamente prejudiciais para o desenvolvimento da atividade turística. Um leve aumento na temperatura global acarretaria o derretimento da calota polar, o que 
levaria ao aumento do nível do mar, o que certamente iria inundar alguns dos principais empreendimentos locais, tais como as ilhas artificiais com formato de palmeira (The Palm) e dos continentes do mundo (The World), onde personalidades como David Beckham e Michael Schumaker possuem propriedades.

Além disso, deve ser destacada a questão dos aparelhos de ar condicionado, os quais são amplamente utilizados em Dubai, devido ao seu clima desértico. Com temperaturas elevadíssimas, é necessário o uso constante desse dispositivo, a fim de se regular a temperatura dentro dos ambientes, tornando possível a habitação dessa região, antes inóspita para o tipo de público que a ocupa atualmente. Acontece que seu uso excessivo promove um aquecimento maior ainda, só que em âmbito global, provocado pela destruição gradativa da camada de ozônio, dado o alto nível de emissão de gás carbônico na atmosfera, fazendo com que isso se torne um ciclo vicioso, pois

“(...) Um ar condicionado de 21.000 BTUs ligado em um ambiente de $30 \mathrm{~m} 2$ a $40 \mathrm{~m} 2$, gasta por hora $2 \mathrm{KWh}$. Ao fim de dois meses, aquela 'horinha' de uso do equipamento todos os dias representa um desperdício de $120 \mathrm{KWh}$. A produção dessa quantidade de energia causa a emissão de 30 quilos de dióxido de carbono (CO2) para a atmosfera, segundo dados do Programa Nacional de Conservação de Energia (Procel). ${ }^{28}$

Sendo assim, fica claro que o meio ambiente configura atualmente um ponto bastante debatido pelo campo das relações internacionais, assim como pelo do turismo. Particularmente importante tem sido a preocupação com o fenômeno do "aquecimento global", que provoca mudanças climáticas impactantes sobre o modo de vida, a economia e a atratividade turística em diversas sociedades no mundo. 


\section{2 - Cultura}

O atual estágio das relações internacionais é caracterizado por uma crescente e irreversível interconectividade política e econômica entre as sociedades nacionais, suas representações estatais e entes privados. Sendo assim, não se pode furtar ao debate das influências culturais de umas sociedades sobre as outras.

Santos $^{29}$, em seu artigo sobre 'Relações culturais internacionais e Teoria Crítica', defende que

“a dimensão cultural das RI diz respeito à conformação de padrões culturais, à disseminação de valores, estilos e sistemas simbólicos sob a forma de políticas culturais específicas que têm suas origens nas máquinas governamentais e/ou mesmo no seio da sociedade civil. Essas políticas resultam em interpenetração cultural (Herz, 1987). As relações culturais entre diferentes povos são marcadas por fenômenos identificados, inicialmente, pela antropologia".

Posto isso, o autor complementa que é importante destacar que, no quadro das áreas que colaboram com as relações internacionais, a antropologia tem um papel bastante relevante. Esta é considerada uma área de suporte, para questões que envolvam problemáticas culturais, tais como religião, relações interétnicas, multiculturalismo, direitos humanos, entre outras. Além disso, a compreensão do conceito de cultura configura uma ferramenta analítica importante para as relações internacionais, especialmente quando a agenda de pesquisa está voltada à compreensão de fenômenos contemporâneos.

Martins (2002) revela que

"Os antropólogos sempre definiram cultura como ‘o modo de vida de um povo'. Desta perspectiva, fala-se em 'cultura indígena', 'cultura européia', 'cultura brasileira'."

A partir desta definição, pode-se concluir que a grandeza da diversidade cultural é bem maior que a quantidade de países do sistema internacional que, em sua maioria são ocupados por diversas etnias, as 
quais não compartilham dos mesmos costumes, além do fato de cada cidade localizada em um mesmo país também apresentar diferenças culturais entre si. E os indivíduos referem sua identidade pessoal ao conjunto de fatores que engloba língua, religião e raça, que juntos, definem sua cultura.

Ainda segundo Martins (2002), a questão do multiculturalismo e das identidades nacionais na Europa, por exemplo, configura um objeto de amplo debate, alimentado nesses últimos anos pelas guerras que seguiram a derrocada do império soviético, principalmente a Guerra do Golfo e pelas controvérsias suscitadas pelo Tratado de Maastricht, que vieram a promover transformações mundiais.

As transformações sistêmicas e seu impacto à teoria das relações internacionais, de acordo com Thaís Sandrim Julião ${ }^{30}$,

"foram responsáveis, em grande medida, pela valorização de temas ligados à cultura e à identidade no contexto de estudos internacionais. Os debates propostos por Huntington e Fukuyama, e entre os dois autores, serão emblemáticos nesse sentido, apesar de não configurarem exatamente uma contribuição científica acadêmica para as teorias de relações internacionais. A vitória do liberalismo e do capitalismo contra o socialismo, o papel da hegemonia e da ideologia e os conflitos interétnicos que se acentuaram no período, são alguns exemplos de temas sensíveis à problemática da cultura e, por extensão, da identidade".

Assim, para uma abordagem sobre a cultura inserida no campo das relações internacionais, é importante fazer uso dos conceitos de cultura, de diplomacia cultural, de soft power e de hegemonia cultural, com o intuito de estabelecer a relação entre os dois temas.

Nesse sentido, a antropologia seria capaz de contribuir com a área de relações internacionais na compreensão de cenários contemporâneos complexos, marcados pela pluralidade de culturas em contatos mais e mais freqüentes e, em muitos casos, conflituosos e violentos.

Segundo Edgard Telles Ribeiro ${ }^{31}$, embaixador do Brasil na Tailândia, 
"o enfoque cultural tanto pode aproximar pessoas e países quando é encarada como patrimônio comum, como pode ser a causa original de conflitos pelo mundo."

Como exemplo desta relação, pode se destacar questões como a ascensão de lideranças indígenas na América Latina e seu papel na política externa dos Estados, e o desafio do terrorismo internacional.

Para o turismo, a questão cultural é acometida pelo mesmo tipo de ambigüidade que atinge o tema 'meio ambiente', já que a cultura e os hábitos de uma determinada população podem sofrer modificações e adaptações, à medida que os contatos entre autóctones e visitantes se intensificam. Corre-se o risco de que o aprofundamento dos vínculos interculturais viabilizados e intensificados pelos fluxos de turistas enfraqueçam as identidades locais que mais atraem os próprios turistas.

Mas, como salienta a OMT (2001), o impacto do Turismo sobre as culturas locais também pode ser positivo.

"o turismo pode ajudar a estimular o interesse dos moradores pela própria cultura, por suas tradições, costumes e patrimônio histórico, uma vez que os elementos culturais de valor para os turistas são recuperados e preservados, para que possam ser incluídos na atividade turística. Esse despertar cultural pode constituir uma experiência positiva para os moradores, dando-lhes certa conscientização sobre a continuidade histórica e cultural de sua comunidade, que, por sua vez, podem se tornar aspectos que potencializem o atrativo turístico do lugar. Dessa forma, o turismo contribui para a preservação e a reabilitação de monumentos, edifícios e lugares históricos e para a revitalização dos costumes locais: artesanato, folclore, festivais, gastronomia, etc."

Isso é um ponto positivo, desde que as manifestações culturais local não percam suas características intrínsecas, com a incorporação de hábitos das culturas dos países emissores, para que não se tornarem apenas um objeto de consumo a mais, levando à chamada cultura-mercadoria ${ }^{32}$. 
Em locais como Dubai, a aculturação vem se tornando algo facilmente detectável, pois crescentes adaptações são incentivadas pelos governantes, a fim de tornar o ambiente mais hospitaleiro e menos hostil aos visitantes ocidentais, de maneira que não haja choques culturais muito relevantes, promovendo uma descaracterização de sua cultura muçulmana, por vezes fundamentalista, remetendo à questão da segurança.

\section{3 - Segurança}

As relações internacionais tiveram como elemento originário de suas preocupações, a guerra. No entanto, outras formas de ameaça ao tema segurança foram surgindo no caminhar da história. Assim, com a evolução e a transnacionalização dos problemas centrais das relações internacionais - a guerra, a paz, o conflito e a cooperação - a questão da segurança deixou de ser um assunto a ser tratado internamente pelos Estados, se tornando alvo de debates multilaterais.

Segundo Dallari (2006), é no século XIX que surgem, sob influência de pensamentos liberais, as primeiras manifestações em prol dos direitos fundamentais do homem, cujos esforços apresentam como marco inicial, a I Conferência Internacional de Paz, na Haia, em 1899. Esta foi seguida de outras tentativas como a Liga das Nações e o Pacto Briand Kellogg no entreguerras, até que em 1945 dá-se a criação da ONU, juntamente com seu Conselho de Segurança, inaugurando o sistema de segurança coletiva, com o intuito de coibir o uso da força. A Carta da ONU vem confirmar esta premissa, já que prevê obrigatoriamente o esgotamento de todos os meios pacíficos para a solução de uma controvérsia, antes que se recorra aos mecanismos coercitivos.

O Conselho de Segurança da ONU, complementa o autor, nasce como o guardião da ordem internacional e, devido à ocorrência de conflitos civis, em detrimento dos conflitos interestatais, passou a autorizar e implementar certos mecanismos coercitivos. Inclui-se nestes mecanismos a intervenção armada de um país ou de uma de coalizão; ou por uma força 
armada, cedida por países integrantes do sistema, sob sua bandeira, para a restauração da paz internacional e com o intuito de prevenir maiores danos, a exemplo das intervenções da lugoslávia e da operação de paz no Haiti respectivamente.

Também configura como preocupação desta organização com relação ao tema segurança, os atos de terrorismo, que segundo o pesquisador Argemiro Procópio, em seu artigo 'Terrorismo e Relações Internacionais', dividem-se em diversas vertentes, dentre elas, narcocriminal, cibernética, financeira, igualitária, repressiva, religiosa, separatista e revolucionária.

O pesquisador coloca, ainda que

"O terrorismo usado tradicionalmente nas guerras é fenomenologia antiga na história da humanidade, anterior ao aparecimento dos Estados Nacionais, nos séculos Xv e XVI. Na falta da ordem e do estado de justiça, a Antiguidade viu o terror como instrumento de barganha e até de esperanças. No atual contexto de desordem internacional, com a globalização selvagem debilitando os Estados nacionais, a história parece repetir a intrínseca natureza transnacional das diversas formas de terror em ação".

Estes temas passaram a ser abordados de forma mais intensa e abrangente pela ONU, após o 11 de setembro de 2001. Para tanto, segundo Raquel Consorte ${ }^{33}$, em seu artigo 'A cooperação internacional à repressão e combate ao terrorismo', no dia 28 do mesmo mês, o Conselho de Segurança determinou que todos os países integrantes da ONU deveriam tomar as medidas necessárias para suprimir as atividades de financiamento e outras formas de apoio ao terrorismo internacional, assim como ajudarem-se mutuamente nas investigações e processos criminais. Além disso, a organização promoveria convenções internacionais concernentes ao terrorismo.

Há ainda, a possibilidade de associação do terrorismo com outros tipos de crimes, como ressalta MacLachlan, apud Consorte. Ele comenta que mesmo 
"o possível envolvimento do terrorismo com atividades ilegais - os seqüestros, as extorsões, as alianças com tráfico de drogas e com o crime organizado - não deixa de considerar o terrorismo como um fenômeno político, e também acredita que a razão de ser dessas ações ilegais é política".

Netanyahu, apud Consorte, conceitua o terrorismo como sendo

"o assalto sistemático e deliberado dos civis para inspirar temor com fins políticos".

Assim como os pontos abordados que prejudicam a segurança são pontos fundamentais para as relações internacionais, são também para o bom andamento da atividade turística.

$\mathrm{Na}$ ocasião do 11 de setembro, muitas medidas tomadas pelo governo americano afetaram direta e negativamente a indústria turística mundial. Com a assinatura da chamada Lei Patriota (USA Patriot Act), que amplia as atribuições policiais para a vigilância e detenção de suspeitos ${ }^{34}$, aumentou-se o rigor no tratamento dos estrangeiros interessados em obter vistos e adentrar o território norte-americano.

As viagens, principalmente internacionais, passaram a ser vistas com certo receio pelos turistas e pelos governos de todo o mundo, devido ao clima de insegurança causado pelo referido atentado. Algumas das principais operadoras de turismo brasileiras, cuja maior fatia de mercado era referente ao destino Estados Unidos, chegaram a quebrar. A cota de mercado turístico americana, no período subseqüente ao desastre, teve uma queda de $12,6 \%$, em relação a $2000^{35}$.

Dada a transnacionalidade do fenômeno terrorismo, este se tornou uma crescente preocupação para os principais governos do mundo, no que tange ao turismo e aos fluxos migratórios, pois, segundo a Revista Época, na publicação "EUA exigem visto até para escala no país", subentende-se que é, também através do movimento inerente a esta atividade, que a rede terrorista se alastra contínua e disfarçadamente.

A segurança local de um país também configura um fator preocupante para ambos os campos, pois alem de afetarem seu próprio país e 
população, podem ter reflexos no exterior, além de colocar a vida de turistas em risco. A atividade turística pode ser prejudicada por falta de condições dadas pelo governo local ou por questões que fogem ao controle do Estado, como é o caso de assaltos, mortes, guerras civis e seqüestros.

Pode ser citado o caso do lêmen, em que quatro turistas franceses foram seqüestrados, em 2006, por uma tribo local durante uma visita ao país. Os dois governos tiveram de interferir nas negociações para que o caso fosse solucionado ${ }^{36}$. Também pode ser mencionado o caso do turista português de dezenove anos, morto em 2006, a facadas, por ter reagido a um assalto na praia de Copacabana ${ }^{37}$, a mais famosa do mundo.

A Guerra do Líbano em 1975 provocou conflitos armados e ataques terroristas, decretando a falência desse pólo turístico. Assim também foi o caso do Chipre, durante a guerra de 1991, pela proximidade com o Golfo Pérsico, no episódio da Guerra do Golfo ${ }^{38}$.

Dubai poderia estar fadado ao fracasso, a exemplo dos dois casos supracitados, por se localizar em meio a este 'campo de batalha'. No entanto, se mostra um exemplo bem sucedido.

\section{4 - Fluxos Migratórios}

Quando o tema em questão é migração, por meio de uma observação histórica, pode-se facilmente constatar a existência de relações de causa e efeito, seja esse movimento temporário, como no caso turismo ou mesmo permanente. Essas causas e efeitos se refletem de maneira decisiva nos estudos das relações internacionais, já que envolvem indivíduos de nacionalidades diversas, países receptores destes indivíduos e, ainda, forças transnacionais as mais variadas.

Os fluxos migratórios datam das primeiras civilizações nômades, atravessaram a Grécia Antiga, os tempos bíblicos e as cruzadas. Mas basta referir-se ao século XIX, durante o qual milhões de europeus se deslocaram para os chamados novos continentes, para que se tenha uma idéia de como estes fluxos estão presentes na construção da história mundial. Segundo 
Antônio Barreto ${ }^{39}$, em seu artigo 'Migrações e Relações Internacionais', durante a maior parte do século XX, muitos países se "fecharam". No entanto, graças ao perfil que o movimento de pessoas adquiriu atualmente, através do advento da globalização, dos novos arranjos internacionais, do turismo e das novas políticas de controlo de fronteiras, o mundo começa a viver um ciclo de relativa abertura.

A despeito desta abertura, o autor destaca alguns pontos positivos desta movimentação, colocando que

"as mais atualizadas investigações arqueológicas, históricas, antropológicas e linguísticas revelam que o movimento e a mistura de populações, por vias pacíficas ou não, estão na origem de enormes progressos da humanidade. A agricultura, a indústria e o comércio desenvolveram-se mais e mais rapidamente naquelas áreas onde era fácil ou foi tornada fácil a movimentação de pessoas e a divulgação de técnicas. E não foram apenas os progressos econômicos e materiais: também as culturas, a escrita, as ciências, a organização das sociedades, a administração pública, a saúde e a educação desenvolveram-se mais e melhor nos continentes propícios ao movimento e às migrações. São também cada vez em maior número os estudos de economistas e historiadores econômicos que tendem a sublinhar, para o tempo contemporâneo, as grandes vantagens puramente econômicas que resultam da imigração de trabalhadores estrangeiros."

As relações internacionais configuram uma destas áreas que obtiveram enormes ganhos com este movimento. Muitos de seus principais teóricos saíam de seus países de origem, a fim de aplicar suas teorias onde eram mais acreditados.

Contudo, existem elementos advindos dos fluxos migratórios que vão contra a paz social e que fazem com que o estudo das relações internacionais estejam, de certa maneira, condicionados a eles. Como exemplo, pode-se citar os movimentos que sejam causados por atos de guerra, conflito, opressão ou conquista, ou por vias de questões políticas, 
religiosas e sociais, que acabam por desencadear perturbações nas sociedades. Há ainda a problemática que envolve a questão da imigração por fatores econômicos, sobretudo quando é feita de modo clandestino, quando pode se verificar a manifestação de xenofobia, conforme será destacado em exemplo mais adiante.

Assim, os movimentos migratórios fazem parte das forças transnacionais e, pela sua dimensão e suas implicações ao cenário internacional, não podem ser ignorados. Para tanto, os atores internacionais promovem constantes atos pelos quais procuram regulamenta-los, tais como diálogos, tratados, políticas e cooperações, de forma a reduzir os impactos das conseqüências que deste movimento advêm.

A formação de blocos regionais entre países de um mesmo continente é uma das formas de superação para problemas sociais dos Estados. Este processo impacta positivamente na atividade turística, já que são adotadas políticas comuns de desenvolvimento econômico, social e financeiro, assim como o livre trânsito de bens e serviços, entre eles os turísticos, facilitando também o trânsito dos viajantes.

No caso europeu, não somente os países membros do bloco são beneficiados por tais medidas, mas brasileiros, por exemplo, passam a ter acesso a todos os países do bloco, sem a exigência prévia de vistos e podem aproveitar a oportunidade para conhecer variadas culturas e localidades durante a mesma viagem. Assim, as fronteiras políticas e ideológicas perdem seu significado, diante deste fenômeno, porém podem ocasionar constrangimentos para alguns viajantes.

O recente caso do imigrante brasileiro, que faria um curso na Espanha e foi submetido a maus-tratos quando da sua retenção pela imigração espanhola, mesmo apresentando documentação apropriada, é um exemplo desse tipo de constrangimento. Não Ihe foi permitido fazer qualquer ligação telefônica, o consulado brasileiro não foi avisado, não the foi oferecido qualquer tipo de alimento durante os dias em que esteve sob custódia da imigração espanhola, dentre outros absurdos. Neste contexto, o desconforto da situação promoveu um diálogo diplomático, a fim de 
solucionar a controvérsia, após sanções migratórias adotadas pelos dois governos, contra visitas de seus nacionais ao outro país em questão. Como se pode notar, esse episódio foi eivado de sérias violações aos direitos humanos, questão esta de grande relevância para ambos os campos de estudo.

\section{5 - Direito Humanos}

Barros-Platieau cita em sala de aula que

"A proteção dos direitos humanos é crescentemente global, não é mais matéria de competência exclusiva das soberanias nacionais, nem pode ser esquivada sob o manto do relativismo cultural".

Em outras palavras, mesmo levando-se em conta o respeito à soberania e às culturas e tradições dos diversos e diversificados povos, devem ser respeitados, em primeiro lugar, os direitos humanos em qualquer parte do globo, independentemente do país, já que existem parâmetros de bem-estar que são comuns a todos os seres humanos.

Segundo o ex-ministro das Relações Exteriores, Celso Lafer ${ }^{40}$,

"Em 'A era dos direitos', Bobbio realça, à maneira de Kant, que um dos sinais positivos do nosso tempo é a importância crescente atribuída ao reconhecimento dos direitos humanos. Este reconhecimento resulta do reforço mútuo dos processos históricos de positivação, generalização, internacionalização e especificação da tutela jurídica dos direitos humanos. O marco inicial da afirmação universal e positiva dos Direitos Humanos foi a Declaração de 1948, da Organização das Nações Unidas (ONU) que inseriu na agenda internacional os direitos humanos como um tema global. Para Bobbio, o antecedente conceitual desta dimensão abrangente é o kantiano jus cosmopoliticum que antecipava o momento em que a violação do direito ocorrida numa parte da terra seria sentida em todas as outras".

Ele completa ainda que 
"a conversão dos direitos humanos num tema global e não circunscrito - o processo da internacionalização - e algumas relevantes facetas do processo de especificação como a Convenção da ONU de 1965 para a Eliminação de Todas as Formas de Discriminação Racial e a Convenção para a Prevenção e Repressão do Crime de Genocídio de 1948, são o resultado de uma política do Direito cuja fonte material foi a sensibilidade axiológica ao horror erga-omnes do mal da descartabilidade do ser humano".

O Brasil ratificou e aderiu a importantes tratados relativos a aspectos específicos da proteção dos direitos humanos. Dentre eles, além dos dois supracitados, estão: a Convenção sobre Asilo Político de 1933; a Convenção sore os Direitos da Mulher de 1952; a Convenção das Nações Unidas contra a Tortura e Outros Tratamentos ou Penas Cruéis, Desumanas ou Degradantes de 1984; a Convenção das Nações Unidas sobre os Direitos da Criança de 1989.

No turismo internacional, esse tema é levado muito a sério, haja vista, principalmente, as diferenças culturais entre os povos. Muitos são os casos em que se pode verificar abuso aos turistas por parte das autoridades do departamento de imigração de diversos países, principalmente quando se trata do fluxo turístico Sul-Norte. Dado o grande número de imigrantes ilegais que desejam viver em um país diverso do seu de nascimento, mas que tenha possibilidades de lhe oferecer melhores oportunidades, acaba ocorrendo uma generalização do modo de tratamento para com o visitante. Isso pode ser verificado no exemplo brasileiro citado no tópico anterior.

Problemas relacionados a direitos humanos são múltiplos no tratamento da força de trabalho do setor turístico de Dubai. Um destes exemplos é o dos trabalhadores da construção civil, os quais constroem boa parte dos atrativos arquitetônicos do emirado, cujos passaportes ficam retidos pelos empregadores até que a obra em questão seja finalizada, ademais as péssimas condições de trabalho, moradia e higiene a que estes são constantemente submetidos. 
No Brasil, o caso mais grave quando se confronta os temas direitos humanos e turismo é a exploração do turismo sexual, infantil e juvenil, facilmente detectável no litoral brasileiro. O Centro de Referência, Estudos e Ações sobre Crianças e Adolescentes apresenta uma definição técnica, na qual o turismo sexual consiste na exploração, principalmente de crianças e adolescentes, por visitantes, em geral, procedentes de países desenvolvidos ou mesmo turistas do próprio país, envolvendo a cumplicidade, por ação direta ou mesmo omissiva do trade turístico. Estudos da ONU demonstram que $75 \%$ dos turistas que desembarcam na cidade de Fortaleza, o fazem a procura de sexo. No entanto, muito tem sido feito para que esse quadro se modifique, através da participação brasileira em fóruns, convenções e eventos afins no país e na América Latina, onde tais questões são veementemente debatidas.

A representação brasileira pelo Professor Doutor Antônio Augusto Cançado Trindade como juiz na Corte da Haia - Corte Internacional de Justiça (CIJ), principal órgão judiciário da ONU, além de este já ter ocupado o cargo de Presidente da Corte Interamericana de Direitos Humanos, demonstra o empenho do país na luta contra as violações aos Direitos Humanos.

\section{6 - Desenvolvimento e Combate à Pobreza}

Não há dúvidas de que existe uma crescente relação entre o tema desenvolvimento e combate à pobreza com as relações internacionais. Não somente os países subdesenvolvidos e os em desenvolvimento demonstram interesses pelo tema, mas também os países ricos, já que a pobreza tem aumentado para todos.

Como cita Pio Penna Filho ${ }^{41}$,

"O século XX foi um século de transformações de grande impacto para a humanidade. Duas guerras mundiais, genocídios, extraordinário desenvolvimento científico e tecnológico são algumas de suas características mais marcantes. Mesmo tendo sido um 
século 'breve', conforme sugere Hobsbawn, o século $X X$ foi um século agitado."

Assim, destaca o autor, com a globalização, nomeadamente a do mercado financeiro, os fenômenos transnacionais passaram a atravessar com maior intensidade a soberania dos Estados, deixando-os mais fragilizados. A falência do socialismo, somada à Terceira Revolução Industrial foram o pano de fundo para a instauração dos pressupostos liberais, logo adotada pelos governos, mormente latino-americanos, em busca do desenvolvimento.

As políticas contrárias ao envolvimento do Estado em questões sociais foram modificadas a partir da participação dos Estados em encontros promovidos por organizações multilaterais. A Cúpula Mundial de Desenvolvimento Social ou Cúpula de Copenhague, de 1995 atrelava o desenvolvimento econômico ao plano social, consagrando o tema como pauta da agenda internacional e tinha como um de seus principais temas o combate à pobreza. A Agenda 21 e a Conferência do Cairo sobre População e Desenvolvimento, de 1994, também trazem o combate à pobreza como condição imprescindível ao desenvolvimento.

Tamanho interesse do assunto para o meio internacional que a ONU chegou a desenvolver, para efeitos práticos, um indicador do nível de pobreza, o IDH (Índice de Desenvolvimento Humano das Nações Unidas). Desenvolveu ainda, o Relatório 2000 sobre Desenvolvimento Humano que mostra bem a situação de pobreza em todo o mundo: mais de um bilhão de pessoas vivem com menos de um dólar por dia; quase três bilhões de pessoas não têm acesso a saneamento básico; há quase um bilhão de subnutridos, à beira da morte; há mais de duzentos milhões de crianças vivendo nas ruas, entre outros dados alarmantes.

Finalmente, há de se salientar a importância crescente que a interação entre a economia política internacional e as relações internacionais vem desempenhando no sentido de influenciar os resultados sociais das políticas econômicas adotadas pelos Estados. 
A despeito das políticas, a OMT (2001) destaca que a atividade turística pode fortemente impulsionar o desenvolvimento e o combate à pobreza, dada a sua simplicidade de implementação, quando comparada a outros ramos de atividade econômica,

“em particular porque a atividade pode ser administrada por pequenos empresários e trabalhadores autônomos e não exige grandes qualificações. Isso não quer dizer que o turismo não possa e não deva sofisticar-se como prestação de serviço, qualificando melhor seus trabalhadores e utilizando mais capital. Significa que, com certa facilidade e de forma relativamente rápida, nas condições atuais de formação dos trabalhadores, é possível envolver economicamente parcelas da população menos qualificadas que se encontram desempregadas quando o turismo se desenvolve".

Dessa maneira, o turismo se mostra uma atividade intensiva em trabalho, podendo absorver grandes contingentes de mão-de-obra ao se desenvolver. Para a economia brasileira, por exemplo, a geração de empregos que a atividade turística promove é incontestavelmente benéfica. De fato, a participação do trabalho no turismo é de 51,5\% do valor agregado, contra $25,9 \%$ referentes à economia brasileira como um todo. ${ }^{42}$

Além disso, como destaca Barreto (2000), “o tema da balança turística está estreitamente ligado a uma questão polêmica no turismo, que é a redistribuição da renda mundial. Na década de 1970, a expectativa dos teóricos era que o turismo fosse um grande redistribuidor de renda mundial. Acreditava-se que haveria um grande fluxo de turistas provenientes de países ricos, trazendo divisas para os países pobres, que seriam visitados por terem ainda atrativos naturais em estado mais puro".

Isso se deve, consorte Fernandes e Coelho (2002), ao fato de o turismo ser considerado um bem de luxo superior, que é mais frequentemente praticado por populações de níveis de renda relativamente mais altos. Nos países do norte concentram-se os emissores de turistas e nos do sul alguns receptores. 
Essa crença na distribuição de renda, se analisada estatisticamente, deve ser levada em consideração, uma vez que pode ser constatado um grande volume de entrada de divisas nos países menos favorecidos, provenientes dos países ricos, através da implementação e da exploração do mercado turístico.

Para exemplificar, os autores destacam o caso da Espanha que pontua um exemplo claro dos benefícios desta atividade para a economia de um país. Após duas guerras consecutivas, o país conseguiu se reerguer graças ao turismo, que veio a se tornar uma de suas principais atividades econômicas, sendo que hoje um a cada seis empregos é garantido a esse setor. Planejamento técnico-científico, exploração de recursos naturais, além da proximidade com diversos dos maiores emissores de turistas, localizados na 'Zona do Euro', possibilitou o alcance da posição desfrutada atualmente por este país no mercado turístico mundial.

Segundo estatísticas da OMT, desde a Segunda Guerra Mundial até 1996, o número de chegadas de turistas internacionais nesse país passou de 2,5 milhões para 61,8 milhões de turistas ao ano. Isso fez com que seu PNB per capta se elevasse a níveis próximos a de seus parceiros da União Européia.

Países que anteriormente adotavam o regime de economia planificada, após o fim da Guerra Fria, por exemplo, tornaram-se fortes pólos turísticos, onde ocidentais, sobretudo de dentro do bloco europeu, satisfazem suas curiosidades sobre a situação social e cultural dos países do Leste Europeu, promovendo desenvolvimento econômico, mediante gastos turísticos nestas localidades. A Croácia configura hoje um dos pontos mais elitizados, visitados por jovens turistas, se comparando a locais há muito tempo renomados como Ibiza, na Espanha.

No Brasil, o problema social das 'favelas' tornou-se um atrativo turístico, empresas do setor se especializaram em promover visitas de grupos de turistas, principalmente estrangeiros, que desejam ver pessoalmente o tipo de vida que se leva em tais comunidades. 
O turismo em Dubai promoveu a troca de uma economia baseada na exploração de petróleo e derivados, para uma baseada em recepção de viajantes milionários, que promovem grandes gastos, garantindo um desenvolvimento surpreendente para o emirado.

Desta maneira, o turismo passa a compor estratégias globais de desenvolvimento, modelando o ambiente, estruturando territórios e preservando tanto o meio ambiente quanto as culturas, promovendo a paz, o crescimento econômico ${ }^{43}$, a justiça e, de maneira geral, a integração e interrelação entre os Estados e suas populações, com forte participação de atores transnacionais.

Destacados os principais temas que correlacionam os campos de estudos das relações internacionais e do turismo, há que se considerar que estes podem obter muitos benefícios por meio de um estudo conjunto. Os temas e agendas das relações internacionais são de fundamental importância para o desenvolvimento da atividade turística, assim como o fomento desta atividade pode colaborar com o a resolução de alguns dos problemas abordados pelos internacionalistas, principalmente no que tange o campo econômico.

Para tanto, Dubai e Brasil são casos a serem analisados, de forma a demonstrar como a adoção das teorias estudadas pelas relações internacionais podem ser benéficas, quando aplicadas de maneira correta. 


\section{4 - DUBAI E BRASIL: DESCRIÇÕES, SIMILARIDADES E DISPARIDADES}

Dubai e Brasil, apesar de este ser um país com dimensões continentais e aquele apenas um pequeno emirado, podem ser comparados de forma a demonstrar a situação de cada um deles, tendo como referencial o turismo, sua estrutura, economia, benefícios e políticas. As duas localidades possuem alguns pontos em comum, mas ao mesmo tempo apresentam disparidades que devem ser abordadas de maneira que se obtenha uma dimensão clara desta comparação.

\section{1 - Dubai: A formação de um emirado cosmopolita}

O Emirado de Dubai, de acordo com site oficial do emirado ${ }^{44}$, estende-se ao longo da costa do Golfo Árabe, nos Emirados Árabes Unidos (EAU), por aproximadamente 72 quilômetros. Possui uma área de 3.885 $\mathrm{Km} 2$ que é equivalente a $5 \%$ da área total do país excluindo-se as ilhas. Possui pouco mais de 1.5 milhões de habitantes, sendo três quartos destes, estrangeiros e, com crescimento do PIB em torno de $19 \%$, mais que o dobro da China. Diz-se, ainda, que Dubai possui 30\% dos guindastes do mundo.

Este emirado foi construído ao longo de um arroio sinuoso e estreito de $10 \mathrm{Km}$, que divide a seção sulista de Bur Dubai, o coração tradicional da cidade, da área do norte de Deira. Os escritórios das matrizes das principais companhias, o Porto Rashid, o Dubai World Trade Center, as alfândegas, as estações de radio e a autoridade postal são todos situados em Bur Dubai. Deira é um centro comercial próspero que contém uma gama enorme de lojas, mercados, hotéis e o Aeroporto Internacional de Dubai.

Segundo Balakrishnan ${ }^{45}$, antes mesmo de tornar-se um emirado, Dubai era apenas uma vila de pescadores e catadores de pérolas que simplesmente sobrevivia destas atividades. Através de uma liderança visionária, deixou de ser esta pequena vila e se tornou um relevante centro comercial, mudança esta facilitada pelo Sheikh Rashid Bin Saeed Al Maktoum. 
O primeiro estimulo foi o pedido de empréstimo ao governo do Kuait, para a dragagem do arroio, a fim de torná-lo mais adequado à navegação em 1959, o maior do Oriente Médio, hoje. A descoberta de petróleo em 1966 ajudou a financiar seu projeto visionário. Em 1970 construiu o porto de Jebel Ali. Seu filho Sheikh Mohammad Bin Rashid Al Maktoum, que herdou o emirado, dá continuidade aos projetos do pai. Além de governador do emirado de Dubai, é Primeiro-Ministro e Vice-Presidente dos EAU. É conhecido por seu perfeccionismo e revê seus projetos-chave pessoalmente.
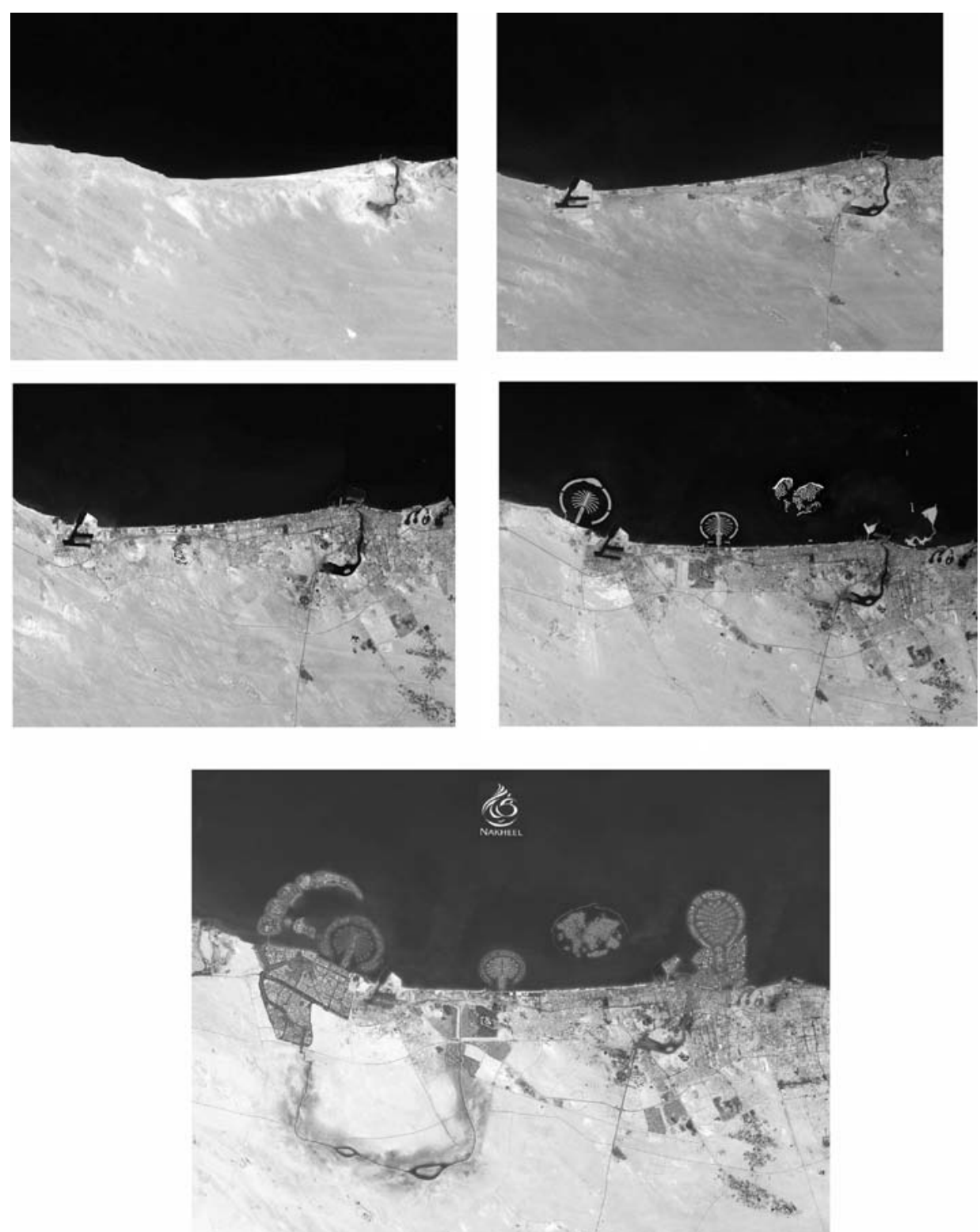

Figura 1: Evolução de Dubai desde 1970, passando por 1990, 2000, 2007 e perspectiva para o futuro 
Dubai fica, na realidade, localizada em meio a um grande, porém disfarçado, deserto no Oriente Médio e sua economia, por muito tempo, foi baseada na prospecção, refino e exportação de petróleo e derivados, até que foi implantada uma zona franca, que possibilitou o incremento do comércio internacional, tornando-o um centro comercial indispensável à região. Deu-se, em seguida, início à exploração turística do local, por meio da implementação de um ambiente que pode ser classificado como um 'não lugar $^{\prime 46}$, devido às fortes transformações que lá se sucederam.

Em 1997, foi criado em Dubai o DTCM (Department of Tourism \& Commerce Marketing). Este veio a substituir o DCTPB (Dubai Commerce and Tourism Promotion Board) existente desde 1989, quando do início da execução do plano de desenvolvimento do emirado. Este órgão é responsável pelo planejamento, supervisão e desenvolvimento do setor de turismo neste emirado ${ }^{47}$. Desde então, o turismo em Dubai vem crescendo substancialmente devido, à proatividade do emirado quanto às mudanças globais, à sua excelente localização e a políticas e ações governamentais associadas ao grande interesse da iniciativa privada, com parcerias internacionais, incluindo-se dentre elas com Donald Trump.

\section{2 - Aspectos econômicos de Dubai}

A economia dos Emirados Árabes Unidos é baseada na exploração de fontes energéticas como petróleo e gás, possuindo a quarta e a quinta maiores reservas de petróleo do mundo, respectivamente. As reservas de Dubai são as menores do país, motivo este que levou à elaboração do 'Plano Estratégico de Dubai 2007', o qual deu seguimento a um plano anterior, cuja meta foi alcançada na metade do período previsto. Este visa fomentar o desenvolvimento social e econômico para os próximos oito anos, onde o turismo configura uma das seis áreas atendidas. A estratégia vem sendo tão bem sucedida que as atividades não-petrolíferas já contribuem com 90\% do PIB do emirado, se tornando um modelo para países vizinhos como Catar, Barein e Omã ${ }^{48}$. 
Sua posição geográfica, no Golfo Árabe, Ihe dá o privilégio de localizar-se a cinco horas de vôo de um terço da população mundial, se configurando como um ponto estratégico para os viajantes provenientes da Europa, do continente africano e do asiático. Isso significava, nos anos 1980, que Dubai era apenas um entrepôt, com quase 50\% de 'passantes', no entanto hoje, cerca de $93 \%$ de seus visitantes viajam a Dubai como destino fim.

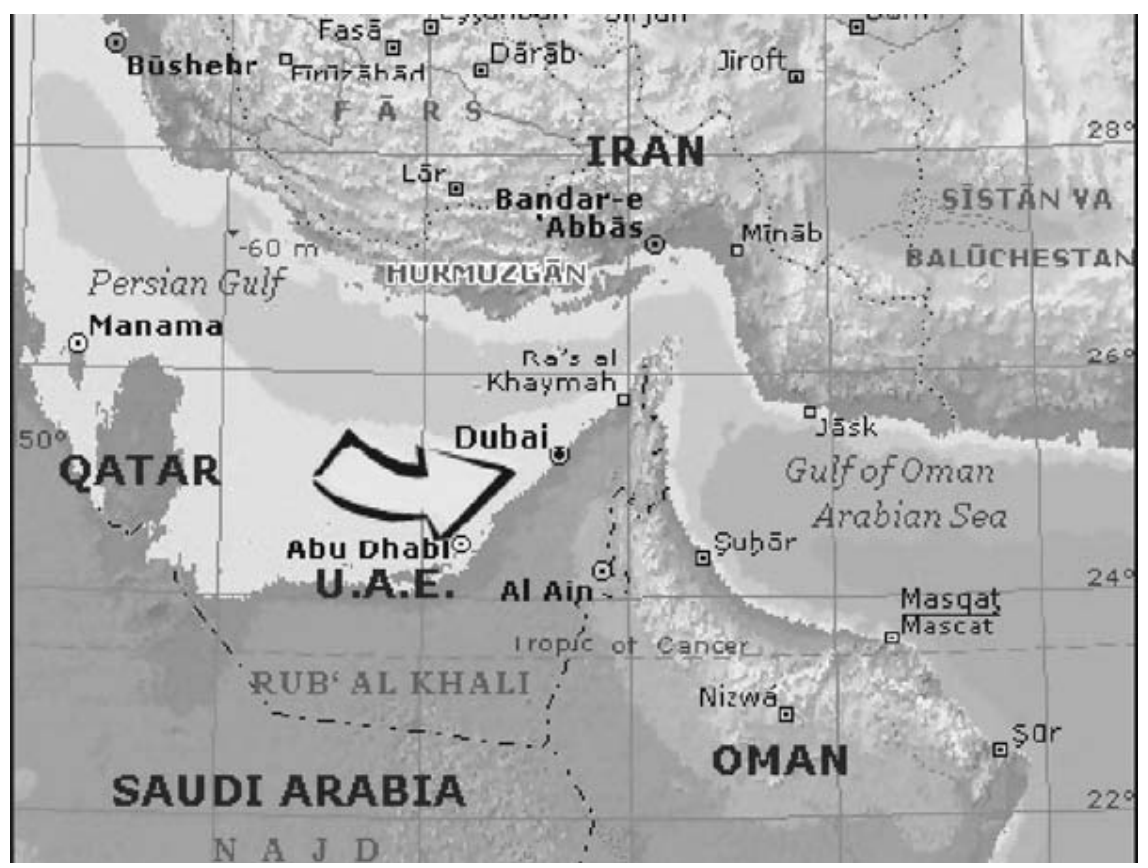

Figura 2: Localização de Dubai

O turismo em Dubai vem conhecendo um crescimento colossal nos últimos 20 anos, tanto que o emirado já possui representantes do seu departamento de comércio e turismo em 16 países $^{49}$, dentre eles o Brasil, que recentemente fechou parceria com este emirado, lançando vôos diretos de São Paulo para Dubai, pela Emirates Airlines. Seu ágil sistema de emissão de vistos produz uma média diária de 15 mil em todo o mundo.

Dubai é uma das economias que mais crescem no mundo, com uma renda per capta registrada em 2005 de US\$31.000. Em 2006, a economia de viagens e turismo do Oriente Médio ocupava o nono lugar no ranking mundial, com investimentos por volta de US\$ 1 trilhão. Os EAU como um 
todo, ocupavam o décimo oitavo lugar, colocando-se como o primeiro lugar no mundo árabe, de acordo com o World Economic Forum. As receitas não petrolíferas dos UAE contribuem com $63 \%$ para o seu PIB, sendo que a contribuição de Dubai fica em $29 \%$ desse total, dentre todos os emirados e com $80 \%$ dos ativos não petrolíferos. ${ }^{50}$

O setor de serviços (imóveis, turismo e varejo) representa três quartos da economia de Dubai, sendo que o setor financeiro responde por $10 \%$ e o de petróleo e derivados, apenas $5 \%$, contra os $36 \%$ do total do país. A atividade turística contribuiu com 18\% em 2006, recebendo 1,875 milhões de visitantes, sendo que a ocupação dos 35.000 leitos dos hotéis ficou em $82 \%$.

\section{3 - A Evolução do Turismo em Dubai: pioneirismo no Oriente}

Nos anos 1980, havia apenas um shopping center em Dubai e hoje existem mais de 50, além dos projetos em andamento. Segundo o professor de economia da Dubai's Zayed University, Wilson Kenneth,

"hotéis extravagantes, praias inundadas de sol, estabilidade política e compras são os fatores primários do crescente número de turistas que visitam o emirado".

Ele diz ainda que os setores de negócios e comércio sempre estiveram presentes na economia, mas a visita a lazer é mais recente ${ }^{51}$.

Os 350 hotéis, dos quais metade é classificada como cinco estrelas, sendo um deles o único 'sete estrelas' do mundo, o Buj al Arab, com o formato de um veleiro, são de tal magnitude de engenharia que o urbanismo arquitetônico por si só pode ser considerado um dos principais atrativos turísticos do local. Uma pista de esqui em pleno deserto, condomínios de luxo em ilhas artificialmente construídas, corrida de camelo, falconismo, safári no deserto, vida noturna agitada, restaurantes de padrão internacional e shopping centers suntuosos com grifes sofisticadas, são apenas algumas das atrações que vem sendo desenvolvidas para atrair um número cada vez maior de turistas endinheirados ${ }^{52}$. 

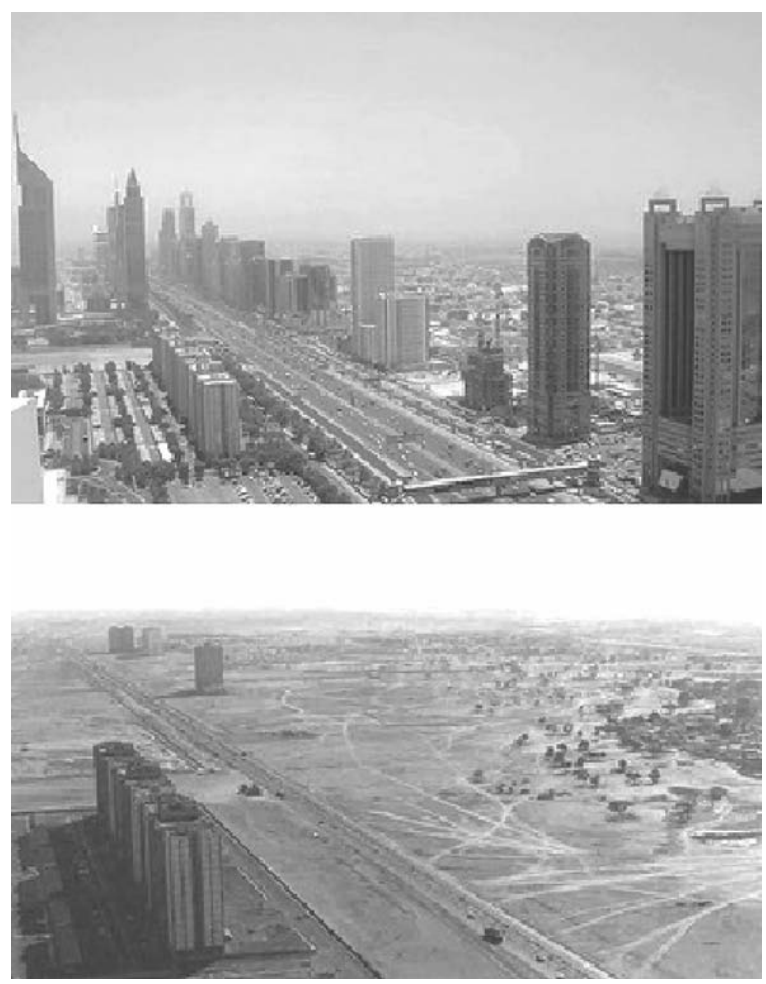

Figura 2: Desenvolvimento de Dubai, primeiro em 2005 e em 1990.

Desta maneira, Dubai pode ser considerado neoliberal, guardadas as devidas proporções, dada à supervalorização do capitalismo traduzida em políticas de abertura de mercado, na implementação da zona franca, incentivos ao Investimento Externo Direto (IED) e também na vontade de lançar-se como um importante mercado financeiro.

Como pode não parecer, Dubai também possui alguns pontos negativos. O meio laboral do país é marcado pela exploração da mão-deobra na construção civil, proveniente principalmente de países asiáticos, considerada por muitos como quase escrava. Isso também se deve à inobservância das condições da população de renda mais baixa, que sofre com problemas de transbordamento de esgoto nas periferias, do trânsito caótico, da carência de transporte público e alto custo de vida, além de estes terem de conviver com certo nível de autoritarismo, onde não existem reais direitos democráticos ${ }^{53}$.

O autoritarismo influencia também na limitação da liberdade de imprensa, nos costumes dos visitantes e dos trabalhadores estrangeiros, sendo que estes últimos chegam a representar 95\% da força de trabalho. 
Eles se submetem a limitações à liberdade, através de um acordo nãooficial, em troca de trabalho e renda. Influencia também no direito penal, pois inúmeros exemplos de ingerência são relatados, em casos de supostos problemas de conduta, levando à prisão do indivíduo e à deportação, sem direito a defesa, caracterizando o choque cultural, que está presente no diaa-dia dessas pessoas.

Outro fator preponderante à sustentabilidade do crescimento de Dubai como pólo turístico é sua dependência energética, resultante da necessidade de grandes quantidades consumidas pelo maior canteiro de obras do mundo ${ }^{54}$, que traz consigo o problema da especulação imobiliária fortemente presente no emirado. Grande parte desta energia é proveniente do gás natural a baixos custos do Catar, qualificando assim, uma grande vulnerabilidade, além de potencializar as já mencionadas alterações climáticas, por der um combustível fóssil.

Assim, Dubai apresenta características marcantes de uma grande cidade ocidental e, simultaneamente, conserva seus valores arraigados da cultura muçulmana, embora muitas vezes suprimidos em prol do desenvolvimento, claramente favorecido por alguns pressupostos neoliberais adotados. Estas características o tornam um local com uma identidade única e cosmopolita que atrai grandes contingentes de nacionalidades as mais diversas, os quais buscam inserirem-se em um contexto beneficiado pelo movimento da globalização.

\section{4 - Brasil: um país com dimensões continentais}

O Brasil é considerado um país de dimensões continentais, não somente devido à sua extensão territorial de 8.514.876,599 km2, suas 27 unidades da federação, seus 5.507 municípios, mas também por sua população de 183 milhões de habitantes ${ }^{55}$, sua abundância em recursos naturais, entre tantas outras vantagens comparativas, quando se tem por referência a maioria dos países do globo terrestre. 
São estes fatores que fazem do Brasil um país com grandes chances de se tornar um global player, além de sua propensão ao desenvolvimento tecnológico. Para o turismo, tais requisitos facilitam a sua implementação como atividade econômica, quando comparados, por exemplo, com Dubai que teve de 'começar do zero'.

Pode-se dizer que o turismo brasileiro, grosso modo, seja dividido em Zona Costeira e Zona Central. A primeira possui uma área de cerca de 7 mil $\mathrm{km}$ de extensão e abrange desde a costa norte à sul do país. Concentra um quarto da população nacional e é a de maior incidência turística, abrigando o chamado turismo "sol e mar". Devido à sua relevância geopolítica veio a se tornar ponto de ênfase na Agenda $21^{56}$.

A Zona Central é onde mais concentra o chamado "ecoturismo", que foi desenvolvido com o intuito de distribuir os fluxos turísticos brasileiros. Este foi fortemente incentivado durante o governo Collor, período da Conferência Mundial Rio-92 e rende bons frutos até os dias de hoje, principalmente no que tange ao turismo doméstico. Esta zona concentra grande parte dos atuais 62 parques nacionais brasileiros, os quais constituem áreas de preservação ambiental. Somando o território de Portugal e o da Inglaterra, pode se obter a quantidade da área de preservação brasileira: quase 22 milhões de hectares. São verdadeiros berçários naturais com espécies ímpares, animais raros e ainda paisagens sem igual como chapadas, cataratas, canyons, cavernas e sítios arqueológicos com pinturas rupestres ${ }^{57}$.

Para administrar todos estes recursos turísticos, foi criada em 1966 a Embratur, anteriormente chamada de Empresa Brasileira de Turismo, o que enfocava essa atividade como uma 'indústria nacional' a ser fomentada. Nos anos 90, passou a se chamar Instituto Brasileiro de Turismo, assumindo as novas regulações promulgadas para a Política Nacional do Turismo, que redesenharam as priorizações antecedentes ${ }^{58}$. Hoje, este órgão é responsável exclusivamente pela promoção do Brasil no exterior, deixando o Ministério do Turismo encarregado do restante das atribuições relativas a esta atividade. 


\section{5 - Histórico das Políticas do Turismo Brasileiro}

Como Becker (2001) expõe em seu artigo 'Políticas e Planejamento do Turismo no Brasil', esta ainda é bastante recente. O primeiro documento legal a abordar algum aspecto da atividade turística no Brasil foi o Decretolei 406, de 1938, que dispunha sobre a venda de passagens aéreas, marítimas e terrestres.

As primeiras regulações, no entanto, foram promovidas em 1958, durante o governo de Juscelino Kubitschek, mas estas eram ligadas ás políticas de transporte e energia. Foi através da gestação da 'classe média do fusca', que se viabilizou a ampliação da circulação mercantil e, consequentemente, o desenvolvimento dos mercados turísticos brasileiros, direcionados principalmente à zona costeira. No entanto, o grande marco institucional dessa política foi a criação da Embratur em 1966, ainda segundo a autora.

Este período foi seguido pelo chamado 'milagre econômico' brasileiro, da década de 70, com altos investimentos em infra-estrutura, aliada a campanhas agressivas de marketing, que incentivaram a classe média a consumir este tipo de produto.

Na década de 80, ainda consorte Becker, o governo Sarney legitimou certa liberalização deste mercado, porém o fato mais marcante foi o início da articulação do turismo com a questão ambiental. Sendo, em 1987, lançado pela Embratur um novo produto de mercado: o Turismo Ecológico. À época, com a crise econômica, a atividade passou a ser encarada como uma alternativa econômica capaz de soerguer as economias deprimidas dos estados nordestinos e de dinamizar a economia da Amazônia, com a 'onda' do turismo ecológico, reforçado pelas opiniões de órgãos como o Fundo Monetário Internacional (FMI), o Banco Interamericano de Desenvolvimento (BID) e o Banco Mundial para a Reconstrução e o Desenvolvimento (BIRD).

Bursztyn (2003) destaca que foi durante o governo Collor, de ideais neoliberais, que a EMBRATUR passou a ter status de instituto. Como resultado dessa nova política, foi implementado, ainda em 1992, o Plantur - 
Plano Nacional de Turismo, para o desenvolvimento regional, que previa a diversificação e a distribuição da infra-estrutura turística, até então concentrada nas regiões sul e sudeste, assim como de um programa de turismo interno de massas, com ênfases nos fluxos dinamizados pelo MERCOSUL.

Ainda neste mesmo contexto, porém sem vínculos com o Plantur, que os governos estaduais do nordeste, reunidos na SUDENE, elaboraram o Prodetur/NE - Programa de Desenvolvimento do Turismo para o Nordeste, que consiste em um programa de crédito para o setor público (estados e municípios). Este visa criar condições favoráveis tanto à expansão e melhoria da qualidade da atividade turística na região, quanto da melhoria da qualidade de vida de suas populações residentes. Ele é financiado com recursos provenientes do BID em parceria com o setor público e com a iniciativa privada. Esta região foi muito beneficiada por este programa, cuja primeira fase foi iniciada em 1994, que já se encontra concluída, dando-se início a sua segunda fase, seguindo o modelo caribenho. ${ }^{59}$

No final do governo Itamar Franco, conclui Becker, foram lançados dois documentos de extrema relevância para as políticas públicas de turismo, as Diretrizes para uma Política Nacional de Ecoturismo, com o intuito de reforçar o potencial ecoturístico de ecossistemas ainda preservados, com forte participação de ONGs; e o Programa Nacional de Municipalização do Turismo (PNMT), que visava a descentralização da gestão e do planejamento da atividade turística nos municípios.

\section{6 - A Economia do Turismo no Brasil}

Atualmente, sob administração de Marta Suplicy, o Ministério do Turismo se esforça para que a atividade tenha a merecida atenção. Segundo a ministra, o setor teve um orçamento de $R \$ 2,5$ bilhões para o ano de 2007,, que havia passado de 0,009\% no ano de 2004 para 0,02 no ano de 2006 do orçamento total da União. Além disso, o Ministério assinou um acordo com o BID para investimentos de R\$ 1 bilhão de dólares no turismo 
brasileiro, sendo parte deste valor investido em qualificação de pessoal e inclusão social. Em pesquisa promovida por este ministério, com 92 das maiores empresas do setor no país, destaca-se que existem 90.211 postos de trabalho, sendo que de 2002 a 2006 houve um aumento de praticamente $70 \%$ na criação de empregos diretos no setor.

Nos últimos cinco anos, de acordo com a Ministra em entrevista ${ }^{60}$, os investimentos no turismo fizeram este saltar para o quinto lugar em relação à obtenção de divisas, superando o setor automobilístico.

Segundo resultados da IV Pesquisa Anual de Conjuntura Econômica do Turismo, da Fundação Getúlio Vargas, o faturamento do setor turístico em 2007 foi de R\$ 34,1 bilhões. Ou seja, cresceu 14,8\% em relação a 2006. Além de terem entrado em 2007 no Brasil, 5,25 milhões de turistas, que estão permanecendo mais tempo no país e gastando mais.

José Francisco Lopes, diretor de Estudos e Pesquisas da EMBRATUR coloca nesta mesma entrevista que

"Estamos fazendo um esforço para aumentar o número de assentos. Entre janeiro e fevereiro de 2007, já conseguimos aumentar em 15\%, ou seja, passou para 1,5 milhões de assentos. Em 2003 registramos 30 milhões de desembarques no Brasil. Em 2007, pulamos para 50 milhões, um salto significativo apenas quatro anos",

Outras referências numéricas puderam ser obtidas a partir das matrizes de contabilidade social estimada para o setor de turismo pelo Centro de Excelência em Turismo (CET) da Universidade de Brasília (UnB). Conforme o PIB, pela ótica da despesa em 2002, apresentou o que se segue: o consumo de turismo das famílias foi de 45.876.970,58 mil reais, enquanto as despesas totais do Brasil, incluindo serviços, indústria, agricultura e o próprio turismo foram de $724.866 .357,45$ mil reais; os investimentos em turismo foram de $216.750,67$ mil reais, sendo que no total, o Brasil teve 219.428.422,05 mil reais de investimentos, incluindo o mesmo grupo de setores citado anteriormente. Estes visam demonstrar a grande disparidade entre gastos e investimentos no setor. 


\section{7 - Análise dos Estudos de Caso a Luz do Neoliberalismo}

As crises econômicas que assolaram o mundo promoveram transformações de grande magnitude, em níveis globais. A atual crise político-econômica ocorre no bojo do longo ciclo de mudanças da economia industrial para uma economia baseada na tecnologia da informação, a chamada Terceira Revolução Industrial.

O liberalismo clássico nasce com a crise do sistema mercantilista colonial e veio a inspirar as idéias neoliberais, cujo aparecimento se dá após a Segunda Guerra Mundial, e sua aplicação, com a ascensão de Margaret Thatcher e Ronald Reagan na Inglaterra e nos Estados Unidos respectivamente. Segundo Berberi e Cobos, este sistema político e econômico passa a oferecer subsídio às mudanças promovidas pela globalização e aparece como uma tendência e até mesmo única alternativa viável frente ao contexto mundial, haja vista que, em sua fase atual, principalmente após a queda do bloco comunista, quase a totalidade dos países do mundo parece se render às políticas neoliberais ${ }^{61}$.

A palavra globalização vem do termo globalismo, que é definido pelos teóricos das relações internacionais Keohane e Nye, apud Sarfati, como

"o estado do mundo envolvendo as redes de interdependência a distâncias multicontinentais, ligadas por fluxos e influências de capital e bens, informações e idéias, pessoas e forças, bem como por substâncias relevantes do meio ambiente e da biologia."

Identificam-se, assim, quatro grandes interações globais: a) comunicação e movimento de idéias; b) transporte e movimento físico de idéias; c) movimentos financeiros e d) viagens e movimento de pessoas.

Nesse contexto, a atividade turística caracteriza-se como global e é absorvida pelas idéias neoliberais à medida que vai se tornando uma importante fonte de receitas aos países que a exploram. Consorte João dos Santos Filho ${ }^{62}$, ela é uma atividade econômica de alto grau de racionalização do capital na busca de maior produtividade, se configurando como uma atividade capaz e propensa a ampliar a reprodução do capital de 
forma rápida e acumulativa, pois seu produto exige um leque de serviços que requer uma massiva e diversa empregabilidade de recursos. Por isso a atividade turística surge como um possível milagre para o sistema capitalista e como elemento capaz de fomentar o crescimento econômico desses países perante a economia global.

Para Harvey (2008), apud Novaes ${ }^{63}$

"o termo neoliberalismo é compreendido como uma teoria das práticas político-econômicas que propõem que o bem-estar humano deve se assentar nas liberdades e capacidades empreendedoras individuais, com uma intervenção mínima do Estado nestes assuntos. Os direitos à propriedade privada e livres mercados são cruciais, o que cabe ao Estado garanti-los".

Dubai, para inserir-se na economia global, foi pioneira no Oriente Médio, no que tange a aplicação de alguns dos pressupostos liberais e neoliberais. Alguns dos pontos que marcam esta nova fase do emirado são o empréstimo tomado, por meio de cooperação, a fim de dragar o arroio e torná-lo navegável; o posterior investimento na atividade petrolífera para a exportação, que veio a financiar o projeto visionário, concretizado posteriormente, caracterizando-se, assim, a atividade de comércio exterior; os crescentes investimentos locais e estrangeiros no mercado imobiliário local, os IEDs; a implementação da zona franca, com fins de desenvolvimento do comércio e de liberalização comercial; o interesse em lançar-se como um mercado financeiro, iniciando-se a liberalização financeira, ou seja a adoção de práticas de economia de mercado, além do fomento do mercado turístico que surgiu a partir das atividades anteriores.

Inicialmente, as viagens a Dubai eram apenas de negócios, mas vieram a se tornar mais amplas (compras, lazer, saúde) dado o espírito visionário e a facilidade de implementação de políticas favoráveis em um governo autoritário, porém desburocratizado, combinação esta que parece dar fôlego ao desenvolvimento da atividade turística em Dubai e contraporse ao caso brasileiro. 
O Brasil se mostra um gigante ineficiente e burocrático a ponto de provocar entraves de grandes magnitudes para que esta e outras atividades venham a se desenvolver, mesmo fazendo uso de alguns pressupostos neoliberais. Quando comparados os números apresentados nas descrições das duas localidades e analisadas as vantagens comparativas que o Brasil apresenta em relação à Dubai, fica difícil entender como este emirado, equivalente a apenas uma pequena cidade do Brasil, desenvolvida artificialmente para esta atividade, consegue superar um país de dimensões continentais, rico em diversos recursos naturais e que parece estar pronto para a exploração de atividades econômicas, como a turística.

À época, no Brasil, também foram adotadas algumas das práticas neoliberais sugeridas a partir do Consenso de Washington, em troca de cooperação financeira. Quando analisadas em curto prazo, elas pareceram ter provocado retrocesso no desenvolvimento do país. Porém, analisadas hodiernamente, é possível verificar que o país conseguiu superar a fase mais crítica do processo de adaptação e parece erguer-se nas bases neoliberais, colocando-se entre os países em desenvolvimento de maior destaque: os BRICs (Brasil, Rússia, Índia e China).

Dentre as principais medidas adotadas pelo Brasil estão a privatização das empresas públicas; a reforma tributária; o regime cambial; a desregulamentação; a liberalização financeira e a comercial, inclusive no campo do turismo, que, desde então, não pára de receber investimentos estrangeiros diretos (IEDs) em seus mais importantes empreendimentos.

Será que a culpa do atrofiamento do setor turístico pode ser atribuída a falta de vontade política, ou ao excesso de corrupção, até mesmo a falta de participação efetiva da população na cobrança de uma atitude eficaz. Será, ainda, a falta de recursos financeiros ou a inobservância dos temas e agendas das relações internacionais. Talvez todas estas características combinadas provoquem os entraves que hoje se apresentam na exploração do turismo como atividade econômica no Brasil.

Apesar disso, nota-se um crescente investimento no setor turístico pelo governo brasileiro, nos últimos anos. No entanto, são muitas as áreas 
que devem ser atendidas pelo orçamento brasileiro, sobrando para o turismo, uma parcela irrisória a ser investida. Já Dubai, possui apenas seis áreas de interesse previstas em seu plano de desenvolvimento, fazendo com que o governo não possua tantos focos de exploração que provoque a diluição de investimentos.

Sendo assim, seria necessário que as políticas públicas brasileiras de cada setor fossem revistas de maneira a balancear os recursos que 0 governo dispõe para que o setor turístico, tão bem explorado por outros países, possa também dar resultados positivos à economia brasileira, gerando todos os benefícios que deste advém, através da aplicação correta de pressupostos neoliberais. No entanto é importante que o uso indiscriminado dos recursos naturais seja rigidamente controlado, a fim de que o país não sofra maiores conseqüências ambientais, provocando prejuízos de outra natureza. 


\section{CONCLUSÃO}

A partir dos dados apresentados no trabalho, pode-se ter idéia de quanto as teorias e os temas das relações internacionais são de extrema relevância para o turismo, assim como das contribuições que a atividade turística pode oferecer para esta disciplina, por se mostrar bastante rentável, conforme apresentados em exemplos, além de fomentador vários dos temas de interesse das relações internacionais. Assim, a confluência das duas disciplinas muito pode contribuir para que seus estudos possam se aprofundar tanto mutuamente, quanto individualmente, haja vista as grandes influências e interligações que um campo tem sobre o outro.

A crescente institucionalização do turismo no mundo demonstra o interesse da comunidade internacional na formação de regras que formalizem esta importante atividade econômica perante os atores internacionais que dela usufruem e se beneficiam.

Os principais temas e agendas das relações internacionais, tais como meio ambiente, segurança, direitos humanos e cultura também se mostram fundamentais para o campo de estudo do turismo, pois estes influenciam de maneira decisiva para o desenvolvimento e à preservação da atividade de maneira geral.

A economia, por exemplo, configura um fator decisivo para as relações internacionais. Assim também o é para o campo de estudo do turismo, haja vista que existem países, ou seja, governos soberanos, que chegam a depender quase que totalmente desta atividade para existir. Isso significa que esta atividade, uma vez deixada de lado por estes governos, poderia provocar a falência, e até mesmo a extinção destas nações e, consequentemente, o fim de sua participação nas instituições internacionais.

Dubai se mostra um exemplo claro de como a atividade turística, associada à aplicação de alguns preceitos neoliberais pode se tornar fundamental para a inserção de uma localidade no contexto internacional. Boa parte do comércio exterior se concretiza através de viagens de negócios, que lá acabaram por se tornar um ponto forte, fomentando, ainda, 
o turismo de compras e o de lazer, devido aos crescentes investimentos e esforços por parte do poder público. Foi a partir de sua abertura econômica que o emirado pode ser visto pelos seus visitantes como um dos maiores centros comerciais do mundo, se tornando um referencial de pioneirismo em todo o Oriente Médio, no que tange à adoção de políticas neoliberais e o desenvolvimento.

O Brasil, devido a diversos elementos, tais como burocracia, centralização do poder, alta diversificação das atividades econômicas, inobservância aos temas e agendas das relações internacionais e políticas públicas ineficazes, apesar de também adotar alguns pressupostos neoliberais para a implementação de atividades econômicas, não consegue alcançar resultados tão benéficos como Dubai, o que seria de extrema adequabilidade para uma economia que já demonstra vantagens comparativas no setor.

Sendo assim, seria interessante que os governantes brasileiros fossem conscientizados de que a atividade turística se mostra mais e mais fomentadora de economias com crescimentos de destaque mundial, para que, então, pudessem valorizá-la a ponto de poder implementá-la de maneira eficaz, mas ao mesmo tempo responsável e desenvolvê-la através de estudos conjuntos com as relações internacionais, para que fosse, na medida do possível, atendido, dentre outros, um dos pontos mais relevantes da política exterior brasileira: o desenvolvimento e combate à pobreza. 


\section{REFERÊNCIAS BIBLIOGRÁFICAS}

\section{Livros:}

BARRETO, Margarida; BURGOS, Raúl e FENKEL, David. Turismo, Políticas Públicas e Relações Internacionais. Campinas, SP: Papirus, 2003.

CUNHA, Licínio. Economia e Política do Turismo. Lisboa:Verbo, 2006.

ALMEIDA, P.R. de. Relações Internacionais e Política Externa do Brasil: Dos descobrimentos à globalização. Porto Alegre: Ed. da UFRGS, 1998.

CRICK, Michael. "Representaciones del Turismo Internacional en las Ciências Sociales: Sol, sexo, paisajes, ahorros y servilismos". In: JURDÃO ARRONES, Francisco. Los mitos del Turismo. Madri: Endymion, 1992.

TURNER, Louis e ASH, John. La Horda Dorada: El Turismo internacional y la periferia del placer. Madri: Endymion,1991.

CUNHA, Licínio. Economia e Política do Turismo. Lisboa: Verbo, 2006

JACKSON, Robert e SORENSEN, Georg. Introdução às Relações Internacionais. Rio de Janeiro: Zahar, 2007.

SARFATI, Gilberto. Teorias de Relações Internacionais. São Paulo: Saraiva, 2005.

KEOHANE, R. O. e NYE, J.S. Transnational Relations and World Politics. Cambridge: Cambridge University Press, 1971.

KEOHANE, R.O. International institutions and state power boulder: Westview: Press, 1989. 
OMT, (2001): Introdução ao Turismo/ direção e redação Amparo Sancho: Traduzido por Dolores Martin Rodriguez Córner - São Paulo: Rocca.

OMT, (2003): Turismo Internacional: Uma perspectiva global. Chuck Y. Gee e Eduardo Fayos-Solá. Traduzido pro Roberto Cataldo Costa. $2^{a}$ edição, Porto Alegre: Bookman 2003.

FERNANDES, Ivan Pereira e COELHO, Marcio Ferreira. Economia do Turismo: Teoria e Prática. Rio de Janeiro: Editora Campus, 2002.

TRIBE, John. Economia do Lazer e do Turismo. São Paulo: Ed. Manole, 2003.

MARTINS, Estevão Chaves de Resende. Relações Internacionais: cultura e poder. Brasília: Funag, 2002.

ALTEMANI, Henrique e Lessa, Antônio Carlos. Relações Internacionais do Brasil: temas e agendas. Brasíia: Editora Saraiva, 2006.

ANDRADE et al. A Economia do Turismo no Brasil. Brasília: SENAC, 2008.

PERCEQUILO, Cristina Soreanu. Introdução às Relações Internacionais: temas, atores e visões. Rio de Janeiro: Vozes, 2004.

DALLARI, Pedro Bohomoletz de Abreu. Temas Contemporâneos de Relações Internacionais. São Paulo: Lex Editora, 2006.

Sites:

www.dubaitourism.com

www.unwto.org

http://portal.unesco.org

http://whc.unesco.org 


\author{
wWw.wttc.org \\ www.estig.ipbeja.pt \\ www.ucs.br \\ www.espacoacademico.com.br \\ www.dubaicity.com \\ www.zawya.com \\ www.conapub.com.br \\ http://noticias.uol.com.br \\ http://meridiano47.info \\ www.santiagodantasssp.locaweb.com.br \\ www.ufrj.br \\ www.visaoportal.com.br \\ www.unifap.br \\ www.scielo.br \\ www.greenbuildings.com \\ www.usp.br \\ www.arquivoetc.blogspot.com \\ www.bndes.gov.br \\ www.unwto.org \\ www.vermelho.org.br
}

\footnotetext{
${ }^{1}$ Barreto, 2003

2 Becker, 2001

${ }^{3}$ Turner e Ash, 1991

${ }^{4}$ Crick, 1992

${ }^{5}$ Barreto, 2003

${ }^{6}$ Barreto, 2003

${ }^{7}$ Almeida, 1998

${ }^{8}$ OMT, 2001

${ }^{9}$ Barreto, 2003

${ }^{10}$ Cunha, 2006

${ }^{11}$ Sarfati, 2005

${ }^{12}$ OMT, 2001

${ }^{13}$ OMT 2001

${ }^{14}$ Cunha, 2006
} 
${ }^{15}$ Sarfati, 2005

${ }^{16}$ Keohane,1989

${ }^{17}$ www.unwto.org

${ }^{18}$ A UNWTO possui 160 países membros e um sistema global de afiliados, ligando milhares de líderes do setor privado, destinos, acadêmicos, ONGs e uma excelente estrutura de parceria público-privada.

${ }^{19}$ www.unwto.org

${ }^{20}$ http://portal.unesco.org - Na Assembléia da UNWTO reuniram-se Ols, ONGs, governos, setores público e privado e a comunidade acadêmica, a fim de se rever os processos, para discutir adaptações e a necessidade de mitigações e opções de políticas na área, através de painéis de discussão.

${ }^{21}$ http://whc.unesco.org

${ }^{22}$ www.wttc.org

${ }^{23}$ www.estig.ipbeja.pt

${ }^{24}$ Jackson e Sorensen, 2007

${ }^{25}$ www.unifap.br

${ }^{26}$ Barros-Platiau, 2006

${ }^{27}$ www.unifap.br

${ }^{28}$ www.energiaeficiente.com.br

${ }^{29} \mathrm{http}: / /$ www.santiagodantassp.locaweb.com.br/br/simp/artigos/santos.pdf

${ }^{30} \mathrm{http}: / /$ meridiano47.info

${ }^{31}$ www.ufrj.br

${ }^{32}$ www.espacoacademico.com.br

${ }^{33}$ www.planalto.gov.br

${ }^{34}$ www.jbonline.terra.com.br

${ }^{35}$ Revista Brasileira de Gestão de Negócios: Ano 06, № 06, Dezembro 2004. Artigo. Análise da importância da taxa de câmbio e do ataque terrorista de 11 de setembro sobre o desempenho do transporte aéreo internacional de passageiros no Brasil. Paulo de Jesus Monçores e Wesley Vieira da Silva.

${ }^{36}$ www.uol.com.br

${ }^{37} \mathrm{http} / / /$ oglobo.globo.com

${ }^{38}$ Barreto, 2003

${ }^{39}$ HTTP:// sorumbatico-longos.blogspot.com

${ }^{40}$ www.visaoportal.com.br

${ }^{41}$ Relações Internacionais no Brasil

${ }^{42}$ Andrade et al, 2008

${ }^{43}$ Lafant e Graburn (apud Barreto, 2003)

${ }^{44}$ http://egov.dubai.ae

${ }^{45} \mathrm{http}: / /$ www.emeraldinsight.com

${ }^{46}$ Este conceito foi elaborado pelo antropólogo Marc Augé, como forma de identificar lugares que não permitem criar identidade. Para o Turismo é a simulação de um lugar turístico em outro ponto do globo terrestre, a qual consegue tornar o sonho de consumo realizável, embora o lugar simulado guarde pouca ou nenhuma semelhança com o lugar onde se localiza.

${ }^{47}$ www.dubaitourism.ae

${ }^{48}$ www.dubaicity.com

${ }^{49}$ Uma destas representações localiza-se em São Paulo, cuja emissão de turistas foi de 10 mil no ano de 2007. O

Brasil é o único país das Américas, com exceção dos Estados Unidos, que recebe vôos da Emirates, companhia aérea de Dubai, conforme acordo fechado entre os dois governos.

${ }^{50}$ http://www.emeraldinsight.com

${ }^{51}$ www.zawya.com

52 www.conapub.com.br

${ }^{53}$ A primeira eleição ocorreu em 2006, com partidos políticos proscritos e pouco mais de seis mil eleitores "selecionados", que votaram um comitê consultor sem poderes, não esquecendo o problema discriminatório contra as mulheres.

${ }^{54}$ Um terço dos guindastes do mundo está atualmente sendo utilizados por Dubai.

${ }^{55}$ www.ibge.gov.br

${ }^{56}$ Becker, 2001

${ }^{57}$ http://viajeaqui.abril.com.br

${ }^{58}$ Bursztyn, 2003.

${ }^{59}$ www.bnb.gov.br

${ }^{60}$ www.g1.globo.com

${ }^{61}$ www.ucs.br

${ }^{62}$ www.espacoacademico.com.br

${ }^{63}$ Consenso de Washington: Crise do Estado Desenvolvimentista e seus efeitos sociais em www.uff.br 